\title{
A review of Paratranes Zimmerman, 1994, Xanthorrhoea-associated weevils of the Tranes group (Coleoptera, Curculionidae, Molytinae), with description of a new species
}

\author{
Yun HSIAO ${ }^{\circledR 1, *} \&$ Rolf G. OBERPRIELER ${ }^{2}$ \\ 1,2 Australian National Insect Collection, CSIRO, G.P.O. Box 1700, Canberra, ACT 2601, Australia. \\ ${ }^{1}$ Division of Ecology and Evolution, Research School of Biology, The Australian National University, \\ Canberra, ACT 2601, Australia. \\ *Corresponding author: yunhsiao@outlook.com \\ ${ }^{2}$ Email: rolf.oberprieler@csiro.au \\ ${ }^{1}$ urn:1sid:zoobank.org:author:6E5C734A-1809-46A1-A595-5A0CB7B39BA0 \\ ${ }^{2}$ urn:lsid:zoobank.org:author:02FE48E2-769B-4A34-A6EA-9B10F6F0C8A7
}

\begin{abstract}
Grasstrees (Xanthorrhoea) are a group of monocotyledonous plants endemic to Australia, with a characteristic crown of long and narrow leaves. In the present study, the grasstree-associated weevils of the genus Paratranes Zimmerman, 1994 are reviewed and two species are recognised: P. monopticus (Pascoe, 1870) and P. zimmermani sp. nov. A lectotype for Tranes xanthorrhoeae Lea, 1898 , which was recently synonymised with $P$. monopticus, is herein designated, and the validity of this synonymy is confirmed. Descriptions and diagnoses of the species are supplemented with photographs of their habitus and salient structures as well as a map of their distributions.
\end{abstract}

Keywords. Grasstree weevils, taxonomy, distributions, Australia.

Hsiao Y. \& Oberprieler R.G. 2021. A review of Paratranes Zimmerman, 1994, Xanthorrhoea-associated weevils of the Tranes group (Coleoptera, Curculionidae, Molytinae), with description of a new species. European Journal of Taxonomy 767: 117-141. https://doi.org/10.5852/ejt.2021.767.1493

\section{Introduction}

The Australian endemic monocotyledonous genus Xanthorrhoea Sm. (Asphodelaceae: Xanthorrhoeoideae), commonly known as grasstrees, comprises 28 species characterised by a crown of long narrow leaves, a secondary thickened meristem and contractile roots. Plants in flower have a long cylindrical inflorescence (flower stalk). Grasstrees vary in height, some species producing tall trunks (up to $6 \mathrm{~m}$ in height) but others not or only subterranean trunks (Lamont et al. 2004; Bush Heritage Australia 2020). Grasstrees play important roles in human culture. Aboriginal people have traditionally utilised them in daily life, e.g., the resin as glue and the flower spikes for fishing spear shafts and firesticks. Due to their unique appearance, grasstrees are nowadays frequently used in amenity horticulture and landscaping. Growth rates of grasstrees are extremely slow, and the populations are severely threatened by an invasive 
soil-borne water mould (Phytophthora cinnamomi Rands), habitat destruction and illegal poaching for the horticultural trade (Lamont et al. 2004; Bush Heritage Australia 2020).

Paratranes Zimmerman, 1994 is a weevil genus endemic to Australia, belonging to the Tranes group of Orthorhinini Jekel, 1865 (Anderson et al. 2018) or placed in its own tribe, Tranini (Legalov 2018; corrected from 'Tranesini' by Hsiao \& Oberprieler (2020)). Unlike the other genera of the Tranes group, which are mostly associated with cycads, Paratranes weevils are associated with grasstrees (Zimmerman 1994; Oberprieler 1995, 2004; Oberprieler \& Caldara 2012; Anderson et al. 2018), having been taken at the base of flower stalks and amongst young leaves (Froggatt 1896, 1907; Lea 1898; Mulder 1964; Hawkeswood 1985). The genus was established by Zimmerman (1994) in his key to the genera of the Tranes group for a single species, P. monopticus (Pascoe, 1870). Zimmerman did not then mention Tranes xanthorrhoeae Lea, 1898, another species associated with grasstrees and presumed by Oberprieler (1995) to also belong in Paratranes, because, based on notes he left in the Australian National Insect Collection, Zimmerman regarded it as being conspecific with P. monopticus. The synonymy of the names monopticus and xanthorrhoeae was only published much later by Pullen et al. (2014), although it was not indicated as a new synonymy and was actually not possible without the designation of a lectotype for xanthorrhoeae and the fixation of the name to one of the two species included in its type series (see below). In his treatment of the Tranes group, Zimmerman (1994) further identified a "new genus, new species allied to Paratranes", which is also associated with grasstrees and which we here recognise as being included in Lea's type series of xanthorrhoeae but representing a different, undescribed species of Paratranes. In this paper we clarify the taxonomy and nomenclature of $P$. monopticus and redescribe it, we describe the new species as P. zimmermani sp. nov. and we illustrate both species with photographs of their adult habitus, terminalia and genitalia and a map of their distributions.

\section{Material and methods}

\section{Specimen depositories}

Examined material is housed in the following collections:

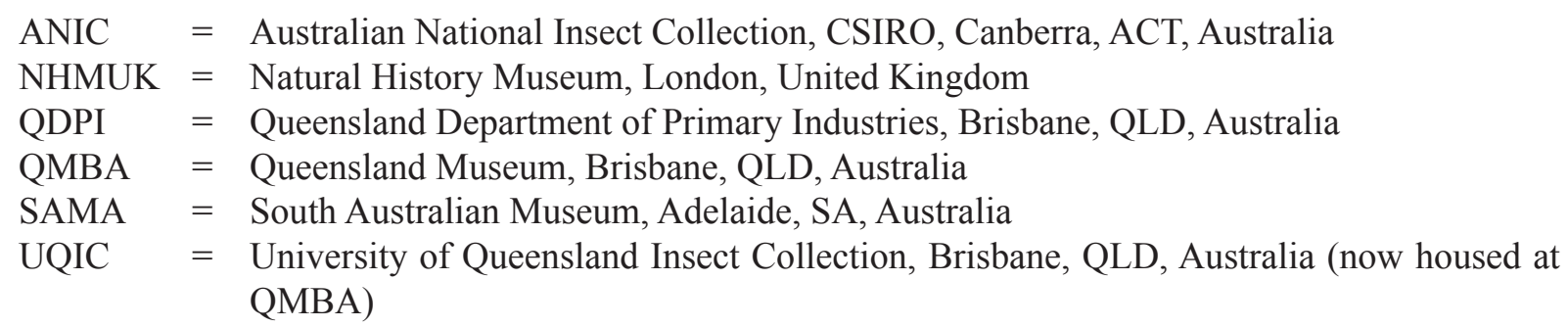

\section{Specimen preparation and photography, measurements and terminology}

Genitalia of both sexes were macerated in $10 \% \mathrm{KOH}$ solution, cleaned and examined under a microscope and temporarily stored in glycerol on slides before permanent storage in microvials pinned beneath the specimens. Photographs were mainly taken using a Leica DFC500 camera mounted on a Leica M205C stereo microscope, with images taken at different focal planes aligned and stacked into highresolution photographs with the software program Leica Application Suite (LAS) V4.9 and edited with the software program Photoshop CS6. Body length was measured from the anterior tip of the pronotum to the apex of the elytra in lateral view, and the width of structures was measured across their widest expanse. Absolute measurements are given in millimetres $(\mathrm{mm})$. Morphological terminology follows Oberprieler et al. (2014). Label data of type specimens are cited verbatim, with a double slash (//) denoting data from different labels and a single one (/) those on different lines on a label. Abbreviations: ex $(\mathrm{x}) .=\operatorname{specimen}(\mathrm{s})$ of unidentified sex. 


\section{Geographical distribution}

The distribution map was generated using the spatial-analysis tool of the Atlas of Living Australia (http://www.ala.org.au) and is based on the label data of all examined weevil specimens and on Paratranes occurrence data in the ALA online database.

\section{Results}

Class Insecta Linnaeus, 1758

Order Coleoptera Linnaeus, 1758

Suborder Polyphaga Emery, 1886

Superfamily Curculionoidea Latreille, 1802

Family Curculionidae Latreille, 1802

Subfamily Molytinae Schoenherr, 1823

Tribe Orthorhinini Jekel, 1865

Genus Paratranes Zimmerman, 1994

Figs $1-10$

Paratranes Zimmerman, 1994: 695.

Paratranes-Oberprieler 1995: 306; 2004: 183 (classification, host associations). - Alonso-Zarazaga \& Lyal 1999: 210 (catalogue); 2014: 560 (classification, host associations). — Oberprieler \& Caldara 2012: 57 (classification, host associations). — Pullen et al. 2014: 289 (catalogue). — Anderson et al. 2018: 2 (classification, host associations). — Legalov 2018: 345 (key, catalogue, classification).

\section{Type species}

Tranes monopticus Pascoe, 1870, by monotypy.

\section{Redescription}

Body slender and depressed, completely shiny black; pronotal and elytral derm nearly nude, covered with very short setae (Fig. 1A). Rostrum moderately long, equally long in both sexes (Fig. 4). Eyes dorsally well separated (Fig. 1C); ventrally very narrowly separated, as narrowly as procoxae (Fig. 1B); forehead slightly narrower than basal width of rostrum (Fig. 1C). Antennae inserted at about distal third of rostrum in both sexes, not sexually dimorphic (Fig. 4); funicles 7-segmented but segment 7 closely approximated to club and nearly continuous in outline with it, segments 1 and 2 short, 2 slightly longer or as long as apical width of scape and slightly shorter than segments $3+4$ (Fig. 5); clubs stout and short, distinctly shorter than funicles, 4-segmented, with small conical apical segment, appearing 5-segmented due to funicle segment 7 being closely approximated to basal club segment. Pronotum distinctly narrower than elytra at humeri, with sides weakly to moderately arcuate (Fig. 3); surface punctate, punctures separate on disc but confluent and vague laterally (Fig. 1D). Elytra elongate, jointly ca $0.5-0.6 \times$ as broad as long, sides subparallel or slightly diverging apicad, subapically slightly indented (Fig. 2A); surface nearly flat (Figs 3-4). Prothorax with anterior margin laterally extended into weak ocular lobes ventrally separated by shallow emargination (Fig. 1B); prosternum before procoxal cavities impunctate or sparsely punctate medially; procoxal cavities confluent, with procoxae contiguous; metanepisterna without sclerolepidia. Femora distinctly sulcate beneath; meso- and metatibiae with distal setal combs continued around apex and extending to almost middle of tibia (Fig. 2B), metatibiae with dorso-apical corner rounded. Terminalia: tergite VII of female subtrapezoidal (Fig. 2C), with posterior margin subtruncate, anterior margin ca $1.5-1.9 \times$ as wide as posterior margin; tergite VIII of male subquadratic (Fig. 2D), with posterior margin subtruncate, of female subtrapezoidal (Fig. 7A, C), very long in P. monopticus, ca $0.9-1.8 \times$ as long as width at anterior margin, posterior margin subtruncate, anterior margin ca $1.4-1.5 \times$ 
as wide as posterior margin; sternite VIII of female with sclerotised parts of apical lobes slender, linear (Fig. 7B, D); tegmen with oval to rounded ring (Fig. 7I-J), manubrium distinctly shorter than parameroid lobes; penis subparallel (Fig. 8), dorsum strongly sclerotised at both sides, forming a broad median groove, apical margin roundly subtruncate or slightly medially emarginate, body distinctly shorter than temones (ca 2.0-3.0×); endophallus (Fig. 8A-B, D-E) membranous, long, extending below body of

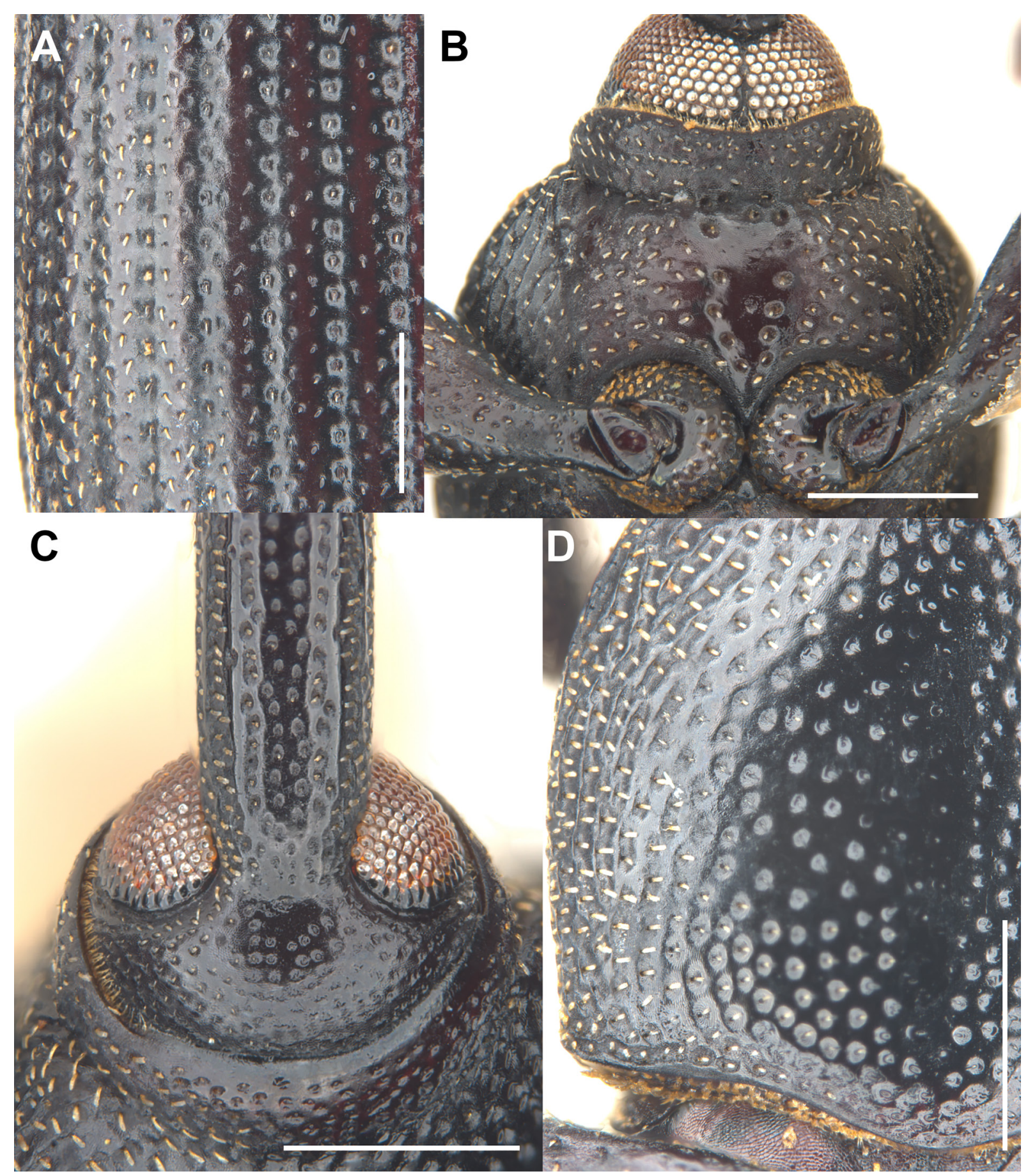

Fig. 1. Diagnostic external characters of Paratranes Zimmerman, 1994. A. Elytral surface and setae. B. Eyes and prothorax, ventral view. C. Head and base of rostrum, dorsal view. D. Pronotal surface. Scale bars $=1.0 \mathrm{~mm}$. 
penis, apically with anchor-shaped symmetrical armature composed of two strongly hooked sclerites joined medially to form a common stalk (Fig. 9A-D); ovipositor short (P. zimmermani sp. nov.) to long $(P$. monopticus $)$, ca $1.5-5.7 \times$ as long as wide, proximal gonocoxite ca $0.8-1.4 \times$ as long as distal gonocoxite (Fig. 10A-B), gonostyli subapical, broad, apically truncate, with few long setae.

\section{Remarks}

Paratranes is here classified in the tribe Orthorhinini, following Anderson et al. (2018), who included the Tranes group in this tribe based on the strongly supported relationship between Tranes Schoenherr, 1843 and the orthorhinine genus Vanapa Pouillaude, 1915 found by Shin et al. (2017) in a robust phylogenetic analysis of 522 protein-coding genes. Without considering these results, Legalov (2018) recently proposed a separate tribe for the Tranes group, Tranini (incorrectly formed as 'Tranesini'; see Hsiao \& Oberprieler (2020)), but his diagnosis of Tranini did not distinguish the group from Orthorhinini, and

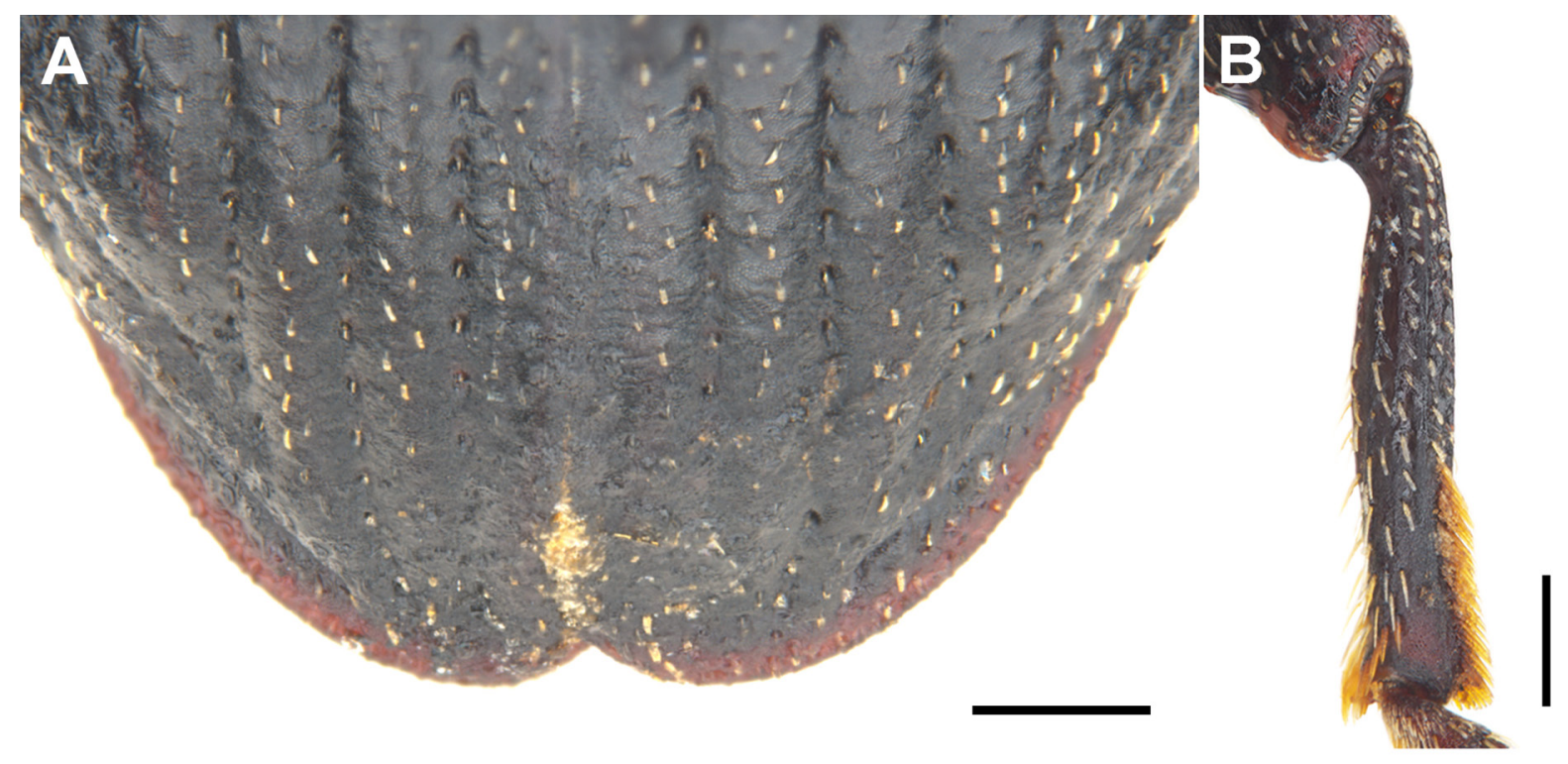

C

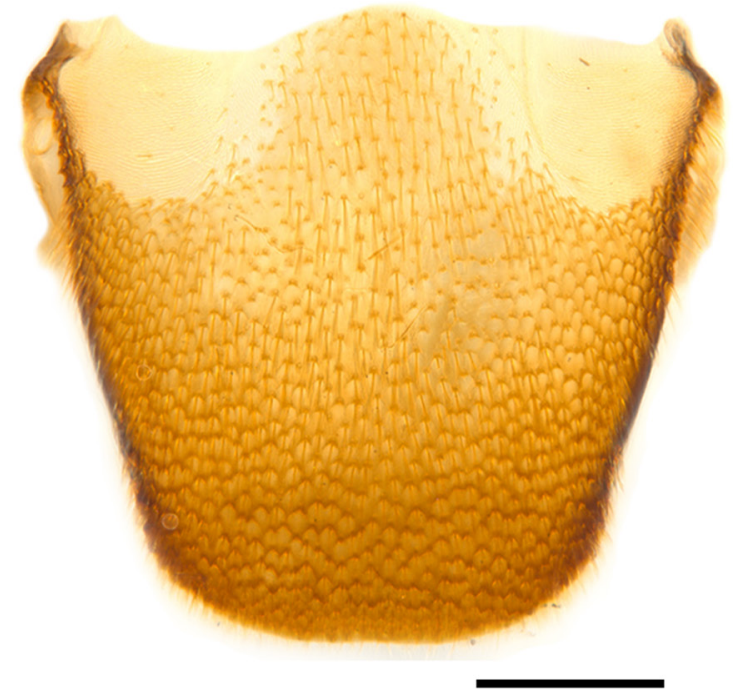

D

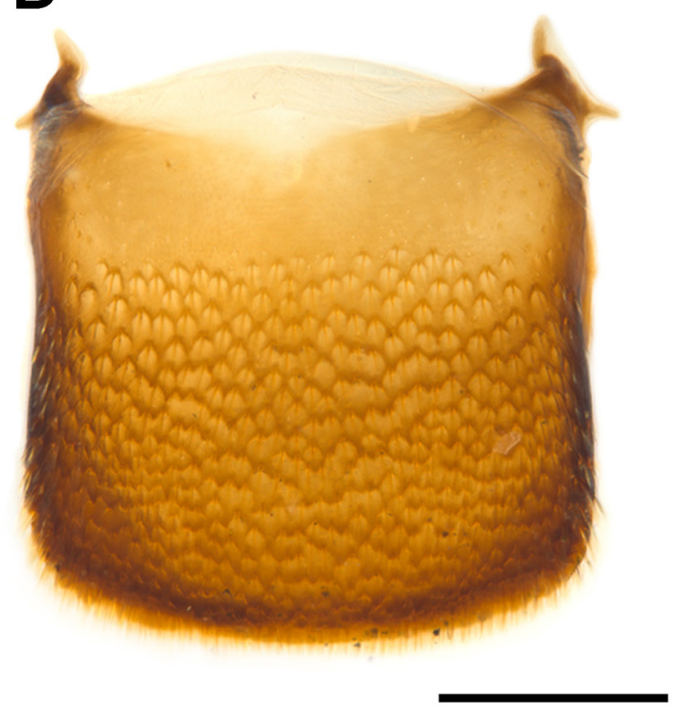

Fig. 2. Diagnostic external characters and terminalia of Paratranes Zimmerman, 1994. A. Elytral apex. B. Right metatibia. C. Tergite VII of female. D. Tergite VIII of male. Scale bars $=0.5 \mathrm{~mm}$. 
it further contained characters not present in all the included genera. Pending further and more detailed analysis of the phylogenetic relationships of the Tranes group, it is premature to afford it tribal status in Molytinae.

The relationships of Paratranes to the other genera of the Tranes group also remain uncertain for the moment. It agrees with Tranes, Miltotranes Zimmerman, 1994 and Howeotranes Zimmerman, 1994 in lacking sclerolepidia along its metanepisternal sutures, which are present in Demyrsus Pascoe, 1872 and Siraton Hustache, 1934 (Oberprieler \& Caldara 2012; Lyal 2014; Hsiao \& Oberprieler 2020), but how closely related it may be to the cycad-associated genera, Tranes and Miltotranes, is as yet unknown. The similarity of the anchor-shaped sclerite of the endophallus in Paratranes and Tranes lyterioides (Pascoe, 1875) suggests a close relationship between these taxa and that Tranes in its current concept may be nonmonophyletic. The taxonomy of Tranes is currently under investigation (unpubl. data 2020).

Paratranes monopticus (Pascoe, 1870)

Figs 3A-B, 4A-B, 5A, 6A, C, E, G, 7A-B, E, G, I, 8A-C, 9A-C, 10A, C, 11-12

Tranes monopticus Pascoe, 1870: 199. Type locality: Queensland, Australia.

Tranes xanthorrhoeae Lea, 1898: 592. Type locality: Darling Range, Western Australia, Australia.

Tranes monopticus - Lea 1898: 594; 1929: 539. — Schenkling \& Marshall 1936: 1. — Oberprieler 1995: 305.

Tranes xanthorrhoeae - Froggatt 1907: 187. - Schenkling \& Marshall 1936: 1. — Mulder 1964: 12. — Oberprieler 1995: 306. — Pullen et al. 2014: 289 (syn.).

Notiosomus (Tranes) xanthorrhoeae - Hawkeswood 1985: 162, 164-165 (habits, distribution).

Paratranes monopticus - Zimmerman 1994: 696. —Alonso-Zarazaga \& Lyal 1999:210. — Oberprieler \& Caldara 2012: 57; Pullen et al. 2014: 289.

\section{Diagnosis}

This species can easily be distinguished from $P$. zimmermani sp. nov. by the following characters (states of P. zimmermani sp. nov. in parentheses): body generally smaller, length $5.2-9.3 \mathrm{~mm}$, width $0.40-0.42 \times$ length (body larger, length $7.3-10.1 \mathrm{~mm}$, width $0.46-0.48 \times$ length); rostrum shorter, ca $1.1-1.2 \times$ as long as pronotum (Fig. 4A-B) (ca 1.3-1.4 $\times$ as long as pronotum; Fig. 4C-D); funicles with segment 2 shorter than 1 (Fig. 5A) (longer than or subqual in length to 1; Fig. 5B); pronotum narrower, sides weakly arcuate (Fig. 3A-B) (wider, sides distinctly arcuate; Fig. 3C-D); elytra narrower and more slender, jointly ca $0.5-0.6 \times$ as broad as long (Fig. 3A-B) (broader, jointly ca $0.6-0.7 \times$ as broad as long; Fig. 3C-D); glabrous region on prosternum oval, longitudinal, distinctly depressed (Fig. 6A) (wider, rounded, not so glabrous, with few sparse punctures, slightly depressed; Fig. 6B); femora ventrally with subapical tooth (Fig. 6C) (edentate; Fig. 6D); protibial uncus distinct (Fig. 6E) (minute; Fig. 6F); tarsal claws thinner (Fig. 6G) (thicker; Fig. 6H); tergite VIII of female elongate (Fig. 7A), ca $1.6-1.8 \times$ as long as wide (shorter, ca $0.9-1.1 \times$ as long as wide; Fig. $7 \mathrm{C}$ ); sternite VIII of female more elongate (Fig. 7B) (shorter and thicker; Fig. 7D); tegmen ring narrower (Fig. 7I) (broader; Fig. 7J); penis slender, ca 1.9-2.0 $\times$ as long as wide (Fig. 8A-C) (thicker, ca 1.4-1.6 $\times$ as long as wide; Fig. 8DF); gonocoxites elongate, slender, ca $3.7-5.7 \times$ as long as wide (Fig. 10A) (shorter and thicker, ca $1.5-2.0 \times$ as long as wide; Fig. 10B).

\section{Material examined}

Holotype

AUSTRALIA • "Holotype // Queensland // Tranes / monopticus / Type Pasc // Pascoe Coll. / 93-60. // Tranes / monopticus Pasc"; NHMUK. 
Lectotype of Tranes xanthorrhoeae Lea, 1898 (here designated) (Fig. 11B)

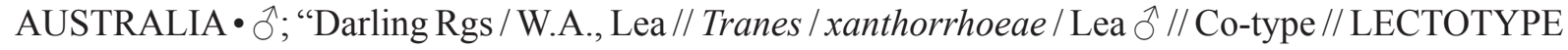
/ Tranes xanthorrhoeae / Lea, 1898 / Hsiao \& Oberprieler des. 2021”; SAMA.

Paralectotype of Tranes xanthorrhoeae Lea, 1898

AUSTRALIA • 1 o; “ “xanthorrhoeae / Lea Galston // PARALECTOTYPE / Tranes xanthorrhoeae / Lea, 1898 / Hsiao \& Oberprieler des. 2021”; SAMA.

\section{Other material}

AUSTRALIA - Western Australia • 1 o ; Pinjarra; "13574 / Tranes / xanthorrhoeae / W. Australia / TYPE [in Lea's hand in red capital letters along right side of label]", "Tranes monopticus c.w.t. 1988, E.C. Zimmerman"; SAMA • 1 क; WA; Ferguson Collection; ANIC • 1 ex.; Geraldton; J. Clark leg.; NHMUK - 1 क; Bowring; ANIC • 1 ex.; same collection data as for preceding; NHMUK • 1 \%; Denmark; ANIC • 1 ô, 2 q $\bigcirc$; Mt Barker; ANIC • 1 ex.; South Perth; 5 Dec. 1903; H.M. Giles leg.; NHMUK • 2 exx.; North Sydney; Oct. 1908; G.E. Bryant leg.; NHMUK • 1 ex.; same collection data as for preceding; 29 Nov. 1908; NHMUK • 1 ex.; same collection data as for preceding; 7 Dec. 1908; NHMUK • 2 exx.; Mt Barker; 1919; A.H. Westley leg.; NHMUK • 2 q o ; Eradu; Sep. 1926; H.J. Carter leg.; ANIC • 1 ठ̊; Deepdene, Karridale; 17 Jan. 1967; M.S. Upton leg.; ANIC • 1 o; Applecross, Perth; 7 May 1967; F.H. Uther Baker leg.; ANIC • 1 \%; Mt Toolbrunup, Stirling Range National Park; 25 Sep. 1975; F.H. Uther Baker leg.; ANIC 1 ex.; same collection data as for preceding; E. Gowing-Scopes leg.; "Tranes monopticus c.w.t.

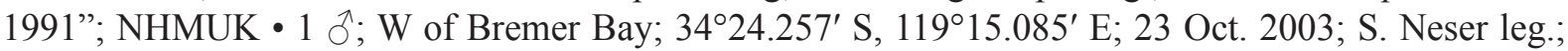
ANIC • 2 ふぇ, 3 q $९$; 17 km E of Harvey; 5 Jan. 1986; C. Reid and P.J. Gullan leg.; ANIC • 2 exx.; Stirling Range, 35 km NE of Kendenup; 34.383 S, 117.994 E; 287 m a.s.l.; 7 Sep. 2009; G.B. Monteith and F. Turco leg.; ANIC. - South Australia • 1 q ; Lucindale; ANIC • 1 Oे, 2 o $\circ$; Lucindale; A.M. Lea leg.;

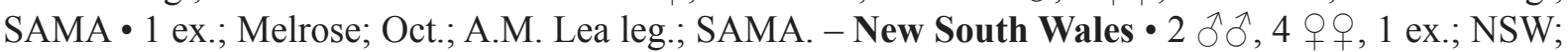
ANIC • 2 exx.; NSW; Fry Collection; NHMUK • 2 exx.; NSW; G.A.K. Marshall Collection; NHMUK - 1 ex.; NSW; Sharp Collection; NHMUK • 2 đิ ô, 1 ค , 1 ex.; Sydney; ANIC • 1 ex.; Sydney, Nat. Park; H.J. Carter leg.; NHMUK • 1 क; Galston; G.C. Champion Collection; NHMUK • 1 ex.; Gosford; Dec. 1931; H.C. Davis leg.; ANIC • 1 \%; Nr. Gosford; 20 Dec. 1931; ANIC • 1 ex.; Palm Beach; 24 Dec. 1933; ex collection A. Walford-Huggins, E. Gowing-Scopes Collection; NHMUK • 1 ; Homebush; 26 Apr. 1941; ANIC • 1 ex.; Nat. Park, Engadine; 8 Dec. 1961; P.L. Cook leg.; NHMUK (BMNH (E)

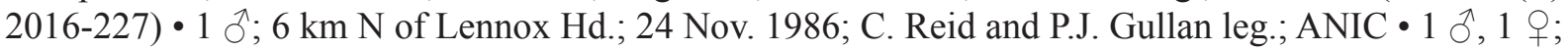
Coonabarabran; ANIC • 1 ex.; Frenchs Forest [Sydney]; Jul. [19]30; ANIC • 1 \%; Rivertree; E. Sutton

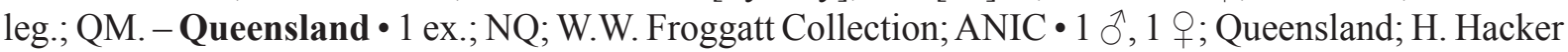
leg.; “Tranes monopticus c.w.t. 1988, E.C. Zimmerman”; ANIC • 1 ठ̊; Cooktown; H. Hacker leg.; ANIC - 1 ex.; Coolangatta; 8 Sep. 1919; F. Muir; ANIC • 1 +, 1 ex.; Yeppoon; 24 Oct. H.J. C[arter] leg.; ANIC

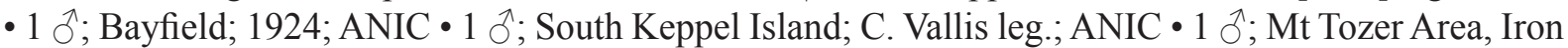
Range; 29 Apr.-1 May 1973; G.B. Monteith leg.; ANIC • 1 đ, 1 ex.; Brisbane, Griffith Uni.; 1978; ANIC - 1 o, 1 ex.; 7 km NE of Tolga; Mar. 1987; Storey and De Faveri leg.; ANIC • 1 +, 1 ex.; Isabella Falls;

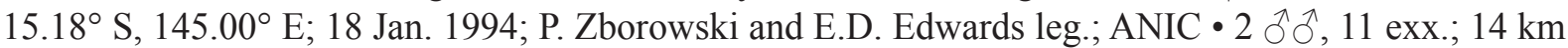

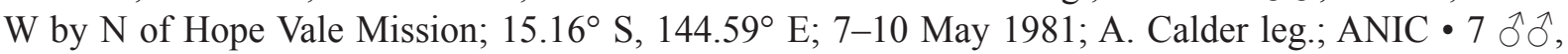
12 우, 17 exx.; 7 km N of Hope Vale Mission; $15.14^{\circ} \mathrm{S}, 145.07^{\circ} \mathrm{E} ; 4$ Oct. 1980; T. Weir leg.; ANIC • $9 \overbrace{}^{\widehat{\jmath}}, 8$ 우; $14 \mathrm{~km} \mathrm{~W}$ by N of Hope Vale Mission; $15.16^{\circ} \mathrm{S}, 144.59^{\circ} \mathrm{E} ; 8-10$ Oct. 1980; T.vWeir leg.; ANIC $-2 \partial^{\lambda}, 1$ क $5 \mathrm{~km} \mathrm{~W}$ by N of Rounded Hill; $15.17^{\circ} \mathrm{S}, 145.10^{\circ} \mathrm{E} ; 7$ Oct. 1980; T. Weir leg.; ANIC - 1 ex.; Heathlands; $11.45^{\circ}$ S, $142.35^{\circ}$ E; 24-28 Feb. 1993; P. Zborowski leg.; ANIC • 1 ठ̊; 91 km S of Coen; 31 Nov. 1978; R.I. Storey leg.; QDPI • 1 ex.; Brisbane, Mt Alder; 13 May 1912; QDPI 3 exx.; same collection data as for preceding; QM 1 ex.; Mt Tambourine; QM 5 exx.; Fletcher; E. Sutton leg.; QM・ 1 ठ; Beenleigh; 24 Apr. [19]28; [prob. E. Sutton leg.]; QM • 2 exx.; Moreton Is.; E.vAllen; QM - 1 ex.; Gordonvale; 1 Feb. 1923; QM • 1 क; Stradbroke Is.; Jan. 1926; E. Kehon leg.; QM • 1 ex.; Mt Tambourine; 18 Dec. 1929; QM • 2 exx.; same locality as for preceding; 14 Dec. 1930; E. Sutton; QM • 

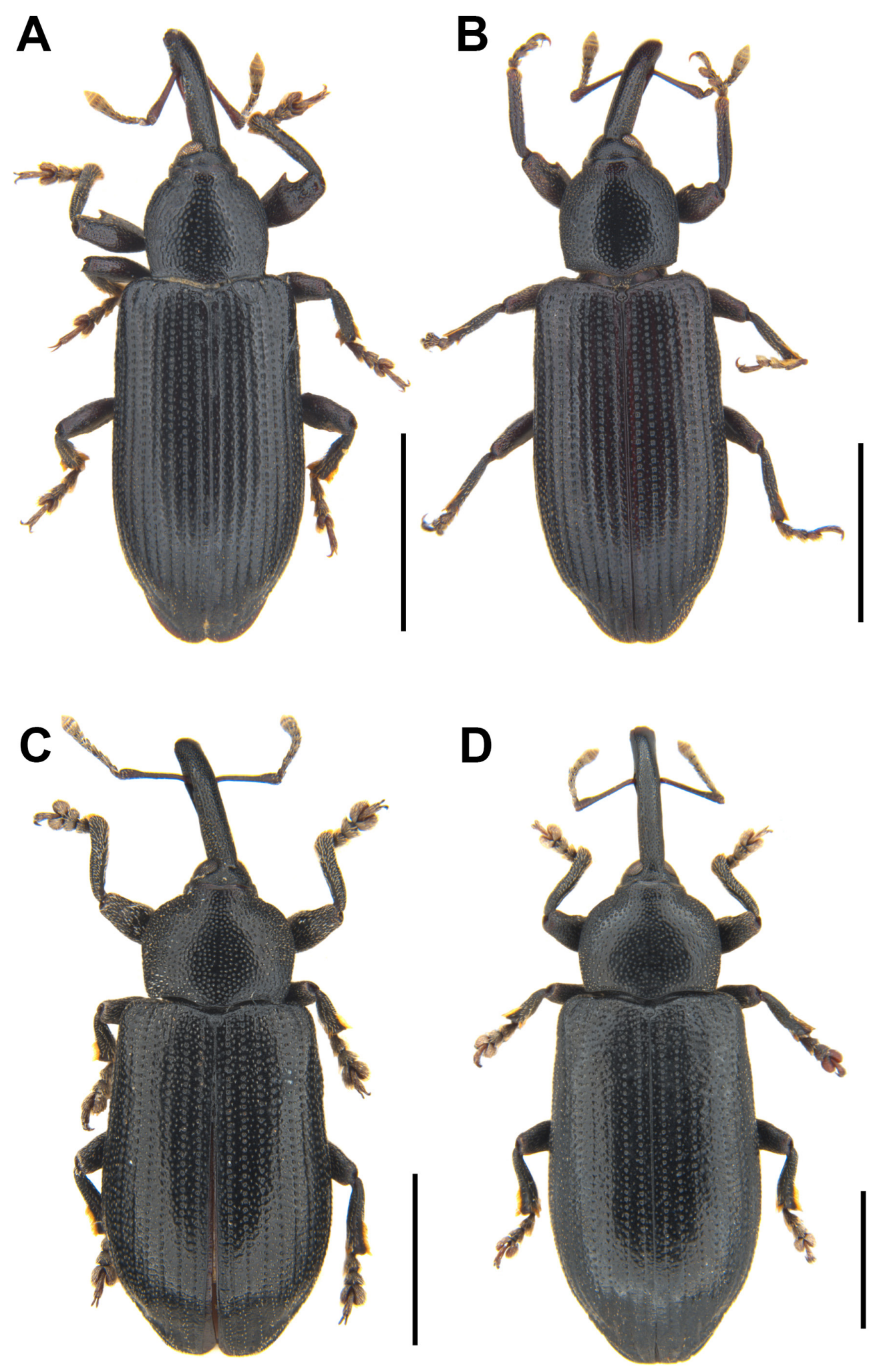

Fig. 3. Habitus, dorsal view. A-B. Paratranes monopticus (Pascoe, 1870). C-D. P. zimmermani sp. nov. (C. Holotype (ANIC); D. Paratype (ANIC)). A, C. Male. B, D. Female. Scale bars $=5.0 \mathrm{~mm}$. 


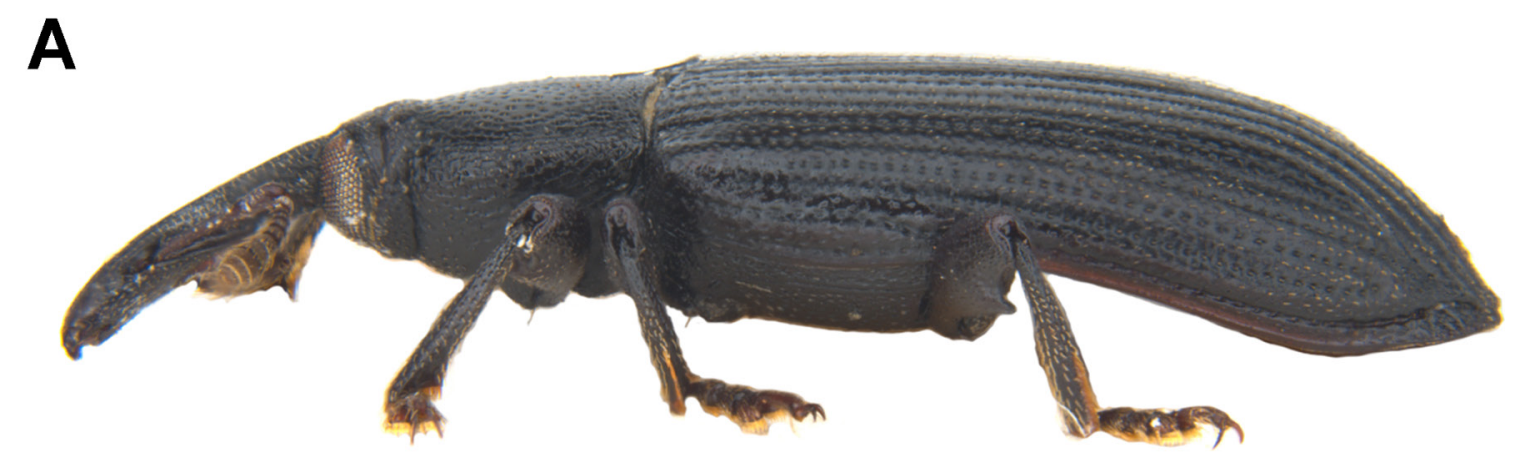

B
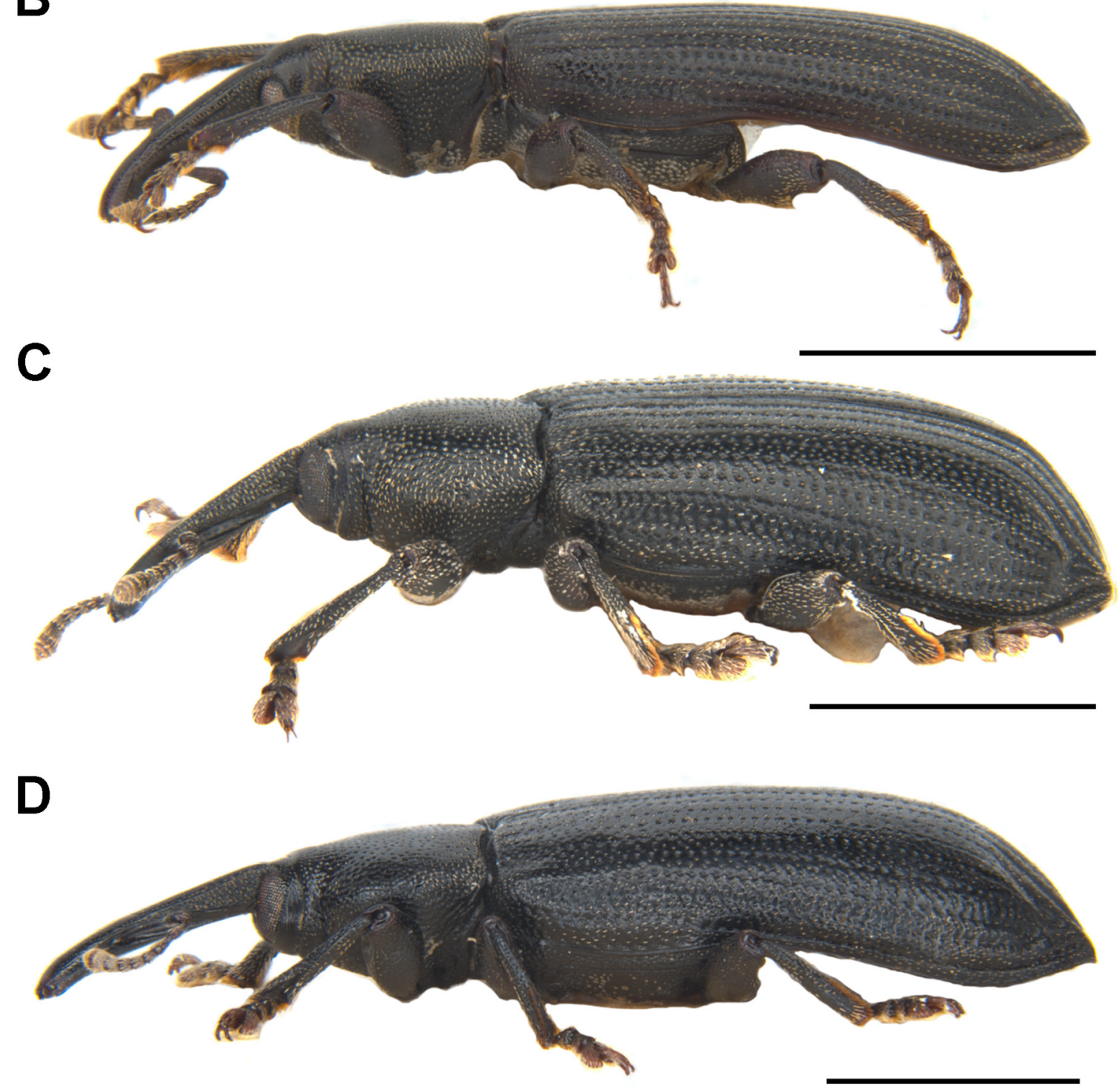

Fig. 4. Habitus, lateral view. A-B. Paratranes monopticus (Pascoe, 1870). C-D. P. zimmermani sp. nov. (C. Holotype (ANIC); D. Paratype (ANIC)). A, C. Male. B, D. Female. Scale bars $=5.0 \mathrm{~mm}$. 
1 ex.; Hambledon; 20 Jan. 1949; E. Sutton and A. Johnson leg.; QM • 1 क; Mt Cleveland Summit, 25 km E Townsville; 13 Jan. 1991; A. Graham leg.; QM • 1 क; Mcllwraith Nth end; $16^{\circ} 49^{\prime}$ S, $144^{\circ} 49^{\prime}$ E; 9 Jul. 1994; Potter, Ingram and Eddie leg.; QM • 1 ex.; Mcllwraith Range, 8 km NE of Coen; 1353.30' S, 143²15.21' E, 540 m a.s.1.; 29 Dec. 1994; G. and A. Daniels leg.; QM • 1 ex.; Mt Nebo Road, powerline; $27^{\circ} 26^{\prime}$ S, 15253' E; 250 m a.s.1.; 23-26 Oct. 2004; G.B. Monteith leg.; QM.

\section{Redescription}

SHAPE AND SIZE. Body elongate oval (Fig. 3A-B), length $5.2-9.3 \mathrm{~mm}$ in both sexes, width $0.40-0.42 \times$ length; very flat in lateral view (Fig. 4A-B).

COlour AND vestiture. Body and legs shiny black, semilustrous; body, femora and tibiae sparsely covered with very short pale setae, setae on tibiae slightly longer than on body and femora; funicles, clubs and tarsi densely covered with yellowish setae, longer than short pale setae on body, femora and tibiae.

RosTRUM. Moderately long, ca 1.1-1.2 $\times$ as long as pronotum in both sexes, robust, faintly evenly curved ventrad, dorsoventrally flattened, slightly broadened apically in dorsal view, coarsely punctate dorsally, punctures very fine in distal half, proximal half with paired dorsomedian and dorsolateral carinae, the latter lower than the former.

EYES. Subcircular in outline, slightly convex but not protruding (Fig. 4A-B).

AnTENNAE. Inserted at about distal third of rostrum in both sexes (Fig. 4A-B); scapes not reaching eye; funicles with segment $1 \mathrm{ca} 1.5-1.6 \times, 1.7-3.2 \times, 2.0-3.2 \times, 2.0-2.7 \times, 1.7-2.0 \times$ and $1.2-1.5 \times$ as long as segments 2 to 7 , respectively; clubs stout, fused with segment 7 of funicle, ca $1.7-1.9 \times$ as long as wide, densely and finely pubescent (Fig. 5A).

Pronotum. Roundly trapezoidal, apex ca $0.6 \times$ as broad as base; anterior margin slightly emarginate medially, posterior margin protruding medially, forming obtuse median lobe, sides weakly arcuate; disc nearly flat; surface densely and coarsely punctate, with elongate longitudinal impunctate region medially, punctures separate but confluent and vague laterally; prosternum with oval longitudinal impunctate depressed region medially (Fig. 6A).

SCUTELLAR SHIELD. Roundly pentagonal to subcircular.

ElYTRA. Ca $3.0 \times$ as long as pronotum, jointly ca $0.5-0.6 \times$ as broad as long, distinctly broader than base of pronotum; humeri broadly rounded, slightly protruding; surface nearly flat, shallowly and coarsely punctate in rows, forming shallowly depressed striae.

LeGs. Femora distinctly sulcate beneath, ventrally with subapical tooth (Fig. 6C); tibiae with arcuate premucro smaller than uncus (Fig. 6E); tarsi with claws free, divergent (Fig. 6G).

Terminalia. Tergite VIII of female subtrapezoidal (Fig. 7A), ca $1.6-1.8 \times$ as long as wide; sternite VIII of male broadly crescentic, sclerotised, apical margin rounded to truncate, basal margin strongly sclerotised (Fig. 7E); spiculum gastrale widely concave apically, base weakly sclerotised (Fig. 7G). Tegmen with complete, oval ring, manubrium slender, distinctly shorter than parameroid lobes (Fig. 7I); penis elongate (ca 1.9-2.0 $\times$ as long as wide), sides straight, parallel or merely slightly diverging apicad, dorsum flat, laterally distinctly sclerotised, medially broadly grooved, apical margin subtruncate (Fig. 8A-C); endophallus with apical sclerite varying from slightly sinuate, emarginate to protuberant (Fig. 9A-C). Gonocoxites narrow, elongate, apically bluntly rounded (Fig. 10A), ca 3.7-5.7 $\times$ as long as wide, proximal gonocoxite ca $1.0-1.4 \times$ as long as distal gonocoxite; gonostyli cylindrical; bursa 
copulatrix without bands of spicules; spermatheca thick, right-angled, gland thick, swollen, narrowing apicad (Fig. 10C).

\section{Distribution}

This species is disjunctly distributed in coastal regions from northern Queensland to central New South Wales (Sydney) and in southeastern South Australia and southwestern Western Australia (Fig. 12). Based on our survey of museum collections, the Queensland population of Paratranes monopticus is the largest and eastern Australia appears to be the main distribution range of this species.

\section{Natural history}

Paratranes monopticus has been reported occurring at the base of flower stalks and leaves and amongst young leaves of Xanthorrhoea (Froggatt 1896, 1907; Mulder 1964; Hawkeswood 1985). Mulder (1964) indicated that the species can attack the green leaves of grasstrees at the base, and the presence of a brownish, mucous secretion at the leaf bases may be linked with the occurrence of this species, although the larvae have apparently not yet been found. According to label data, specimens can be attracted by

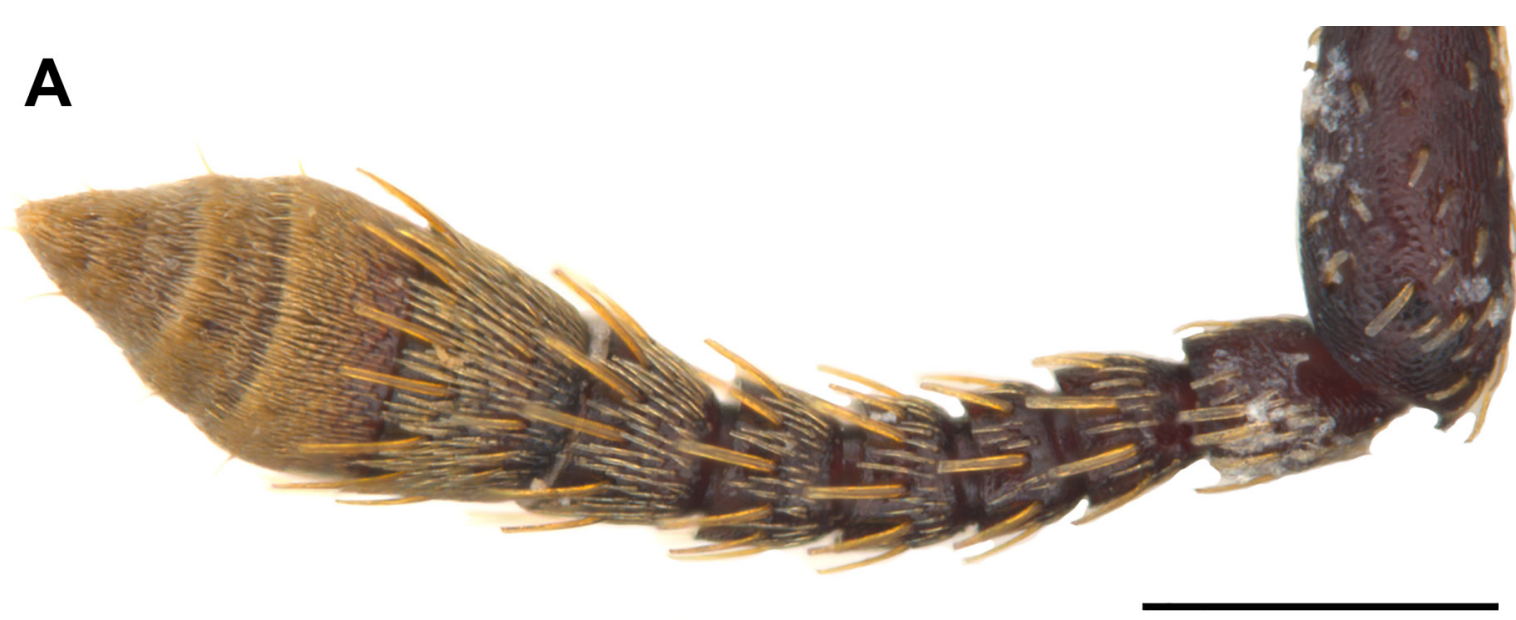

\section{B}

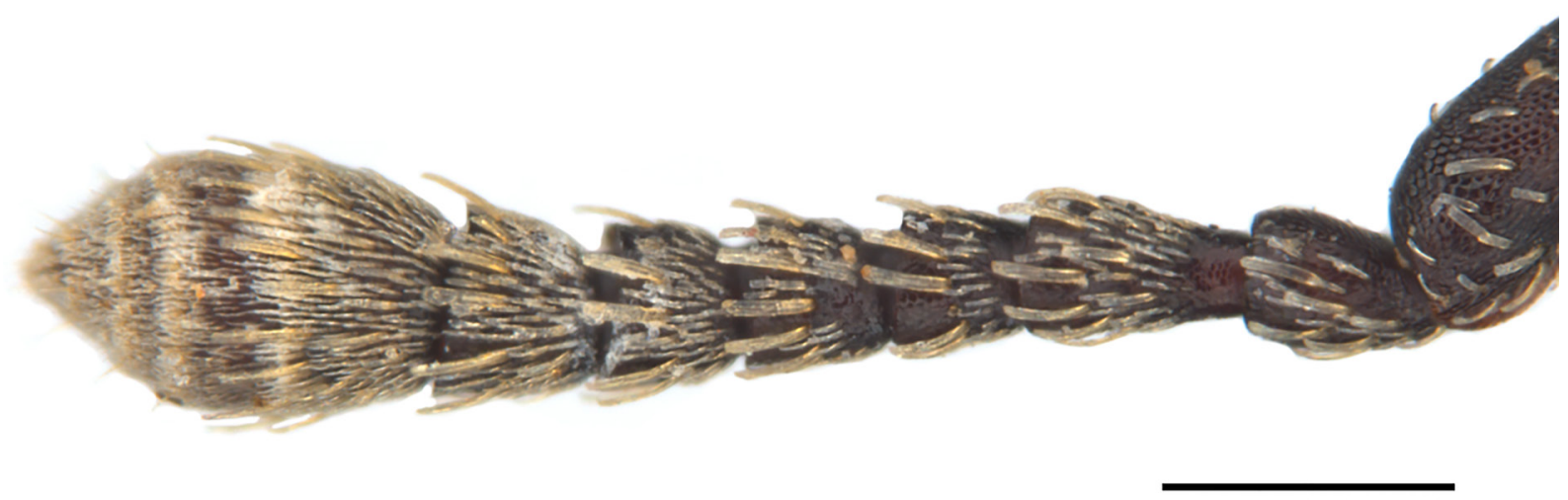

Fig. 5. Left antenna, dorsal view. A. Paratranes monopticus (Pascoe, 1870). B. P. zimmermani sp. nov. Scale bars $=0.5 \mathrm{~mm}$. 
mercury-vapour lamps, but this does not necessarily indicate a nocturnal behaviour and may just relate to specimens disturbed from grasstrees growing near the lights, as happens with Tranes weevils and cycads. Based on records by Hawkeswood (1985) and label data, $P$ monopticus is associated with at least three species of grasstrees ( $X$. australis $\mathrm{R} . B r$., $X$. johnsonii A.T.Lee and $X$. preissii Endl.), but it probably occurs on others as well and is likely not host-specific.

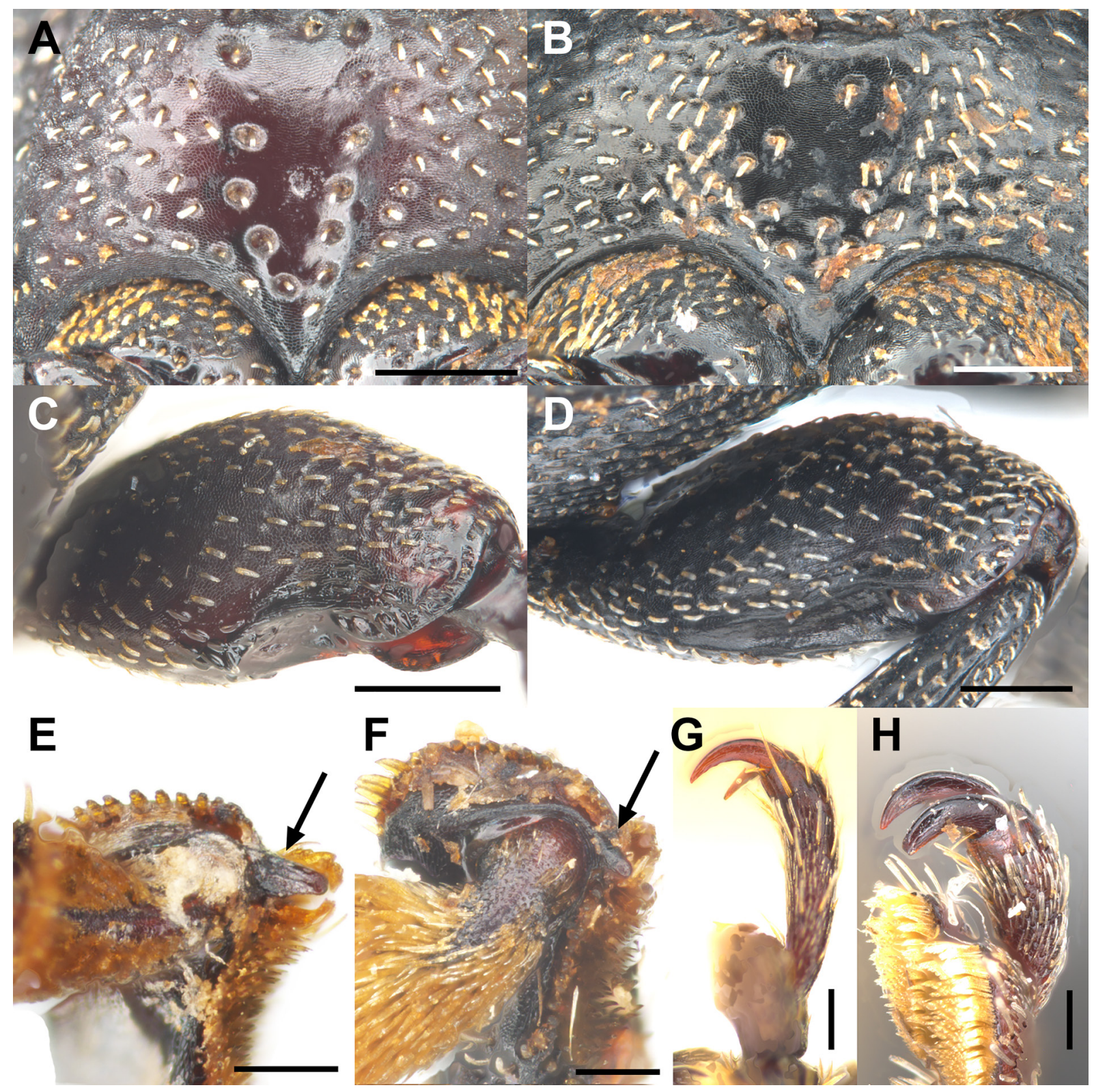

Fig. 6. Diagnostic differences of external characters between Paratranes monopticus (Pascoe, 1870) and P. zimmermani sp. nov. A. P. monopticus, prosternum. B. P. zimmermani sp. nov., ditto. C. P. monopticus, profemur. D. P. zimmermani sp. nov., ditto. E. P. monopticus, protibial uncus, indicated by black arrow. F. P. zimmermani sp. nov., ditto. G. P. monopticus, terminal tarsal segment with claws, lateral view. H. . zimmermani sp. nov., ditto. Scale bars: $\mathrm{A}-\mathrm{D}=0.5 \mathrm{~mm}$; $\mathrm{E}-\mathrm{H}=0.2 \mathrm{~mm}$. 

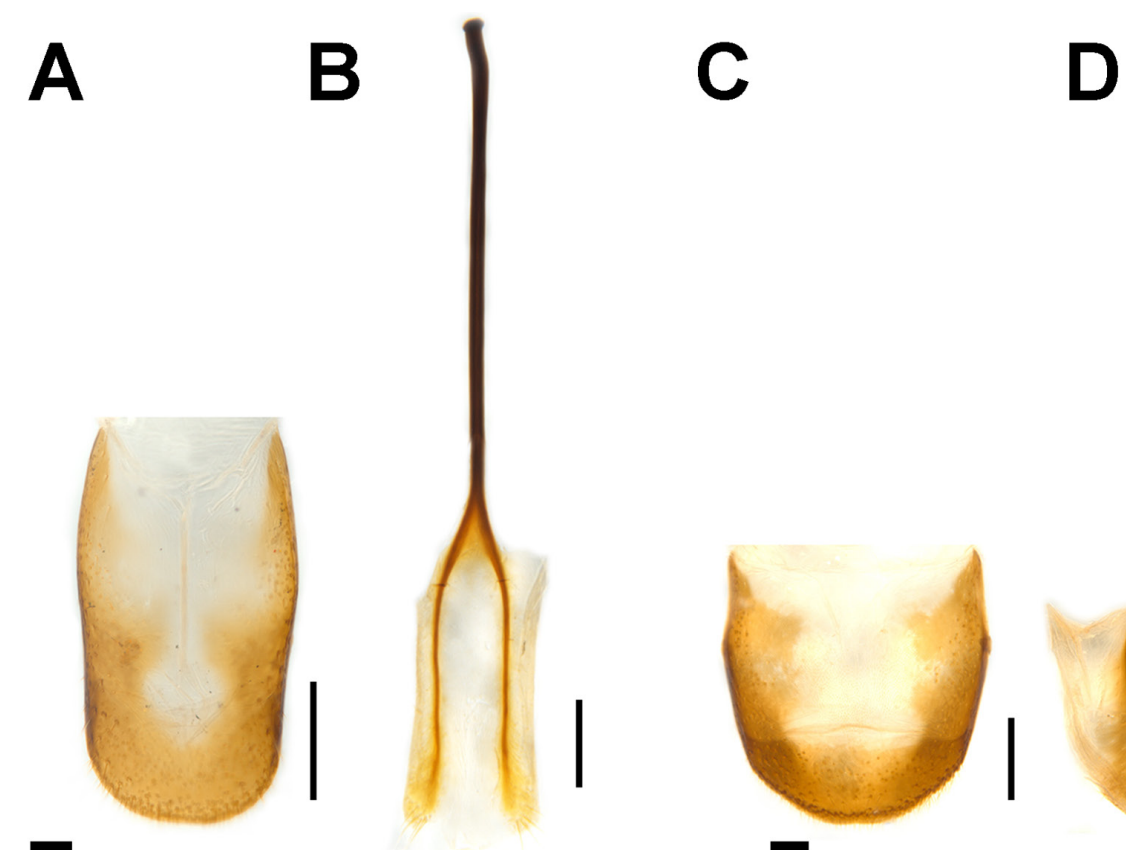

E
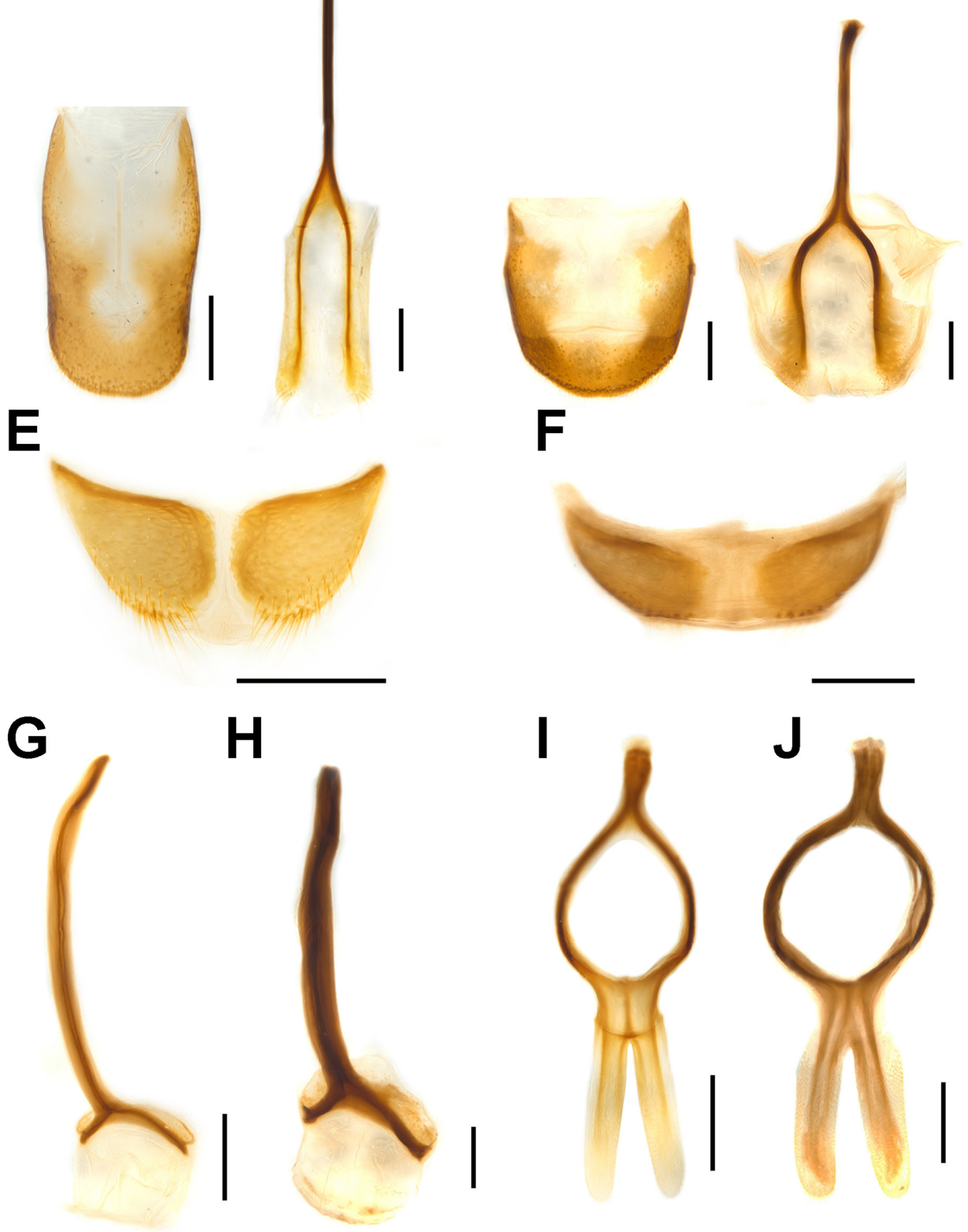

Fig. 7. Terminalia of Paratranes Zimmerman, 1994. A. P. monopticus (Pascoe, 1870), tergite VIII of female. B. P. monopticus, sternite VIII of female. C. P. zimmermani sp. nov., tergite VIII of female. D. P. zimmermani sp. nov., sternite VIII of female. E. P. monopticus, sternite VIII of male. F. P. zimmermani sp. nov., sternite VIII of male. G. P. monopticus, spiculum gastrale. H. P. zimmermani sp. nov., ditto. I. P. monopticus, tegmen. J. P. zimmermani sp. nov., ditto. Scale bars $=0.5 \mathrm{~mm}$. 


\section{Remarks}

The taxonomy and nomenclature of P. monopticus is complicated, because the type series of the synonymic name xanthorrhoeae comprises two different species and its author (Lea 1898) did not validly (in the description) designate a primary type, so that all specimens of the type series are syntypes. Lea also did not specify the number of specimens on which he based the description of xanthorrhoeae, but he cited the specimens as having been collected at seven localities, as "Hab. - Darling Ranges, Mt. Barker, Bridgetown, Swan River, W.A.; Galston, Gosford, Sydney, N.S.W.". There are seven specimens from these locations in Lea's collection (in SAMA) and the ANIC (see Material examined), but there are two from Sydney and none from Bridgetown, and only the three specimens from WA (Darling Ranges, Mt Barker and Swan River) are labelled as 'Co-types' by Lea. A further specimen in his collection is labelled "xanthorrheae [sic] / Lea TYPE / Pinjarrah" and also carries a large label with Lea's handwriting "Tranes / xanthorrhoæ / W Australia" and "TYPE" in red lettering along its right side, as is typical of specimens that Lea regarded as the primary types of his species names. However, as Pinjarra is not mentioned as a locality in the description of Tranes xanthorrhoeae, it appears that Lea may not have had this specimen when he described the species and it cannot therefore be regarded as belonging to the type series and be treated or designated as the name-bearing type of Tranes xanthorrhoeae.

In his description of the species, Lea (1898) noted that some of his specimens were larger and wider (especially the elytra), had a longer and thinner rostrum, the glabrous region on the prosternum wider and less noticeable and, most notable, edentate femora, and he regarded these specimens as representing the female of his new species. Zimmerman later recognised that these so-called females actually represent a different species, and he noted this on a copy of Lea's description (kept among his notes on the Tranes group in the ANIC), and later he even regarded these specimens as representing a new genus "allied to Paratranes" (Zimmerman 1994). On his copies of the descriptions of Tranes monopticus and T. xanthorrhoeae he further wrote that he had borrowed the type specimen of monopticus from Pascoe's collection in the Natural History Museum in London in 1988 and, comparing it with the "male" types of Lea's xanthorrhoeae (in particular the specimen from Pinjarra, which he accepted as the "holotype"), he concluded that the types of monopticus and xanthorrhoeae represent the same species. According to his notes, the synonymy of these two names had in fact earlier been suggested to him by John BalfourBrown (of the Natural History Museum, London) - although a specimen so labelled by Balfour-Brown, from the Stirling Range in WA, is in fact P. zimmermani sp. nov. (see there). Zimmerman did not, however, effect this synonymy in his description of Paratranes (Zimmerman 1994), and it was only published much later by Pullen et al. (2014) (although it was actually not possible to synonymise the names without designating a lectotype for xanthorrhoeae and fixing the name to one of the two species represented in Lea's type series).

From our thorough examination of all available material of Paratranes, including of the male genitalia of many specimens, we conclude that the type series of xanthorrhoeae indeed comprises two distinct species, as Zimmerman had recognised, and furthermore that the syntypes from the Darling Range in WA and Galston in NSW represent $P$. monopticus (as determined by comparison with the holotype of monopticus (Fig. 11A) and specimens "c.w.t." (compared with the type) of monopticus by Zimmerman) and that those from Mt Barker, Swan River, Gosford and Sydney belong to a different species. In order to fix the name xanthorrhoeae to one of these two species, we here designate the male syntype from the Darling Range (Fig. 11B), which agrees well with Lea's description, as the lectotype of xanthorrhoeae and the other six specimens of the type series as paralectotypes. This lectotype designation and comparison of the lectotype with the holotype of monopticus enable us to validate the synonymy of monopticus and xanthorrhoeae published by Pullen et al. (2014) and to describe the other species as new, here named P. zimmermani sp. nov. The paralectotypes of xanthorrhoeae from Mt Barker, Swan River, Gosford and Sydney are further designated as paratypes of $P$. zimmermani sp. nov. Specimens of P. monopticus from Western Australia and South Australia differ slightly from those from Queensland (the type locality) 
and New South Wales by having the apical margin of the genital sclerite of the endophallus medially not straight (Fig. 9A) but slightly emarginate (WA) or lobed (SA) (Fig. 9B-C). Based on the records available to us, the WA and SA populations also appear to be geographically separated from those in eastern Australia, but in the absence of significant morphological differences we interpret all populations to represent a single, somewhat variable species.

Paratranes zimmermani sp. nov.

urn:1sid:zoobank.org:act:25298AC5-CC8A-4E10-8DA1-D5137DCE0776

Figs 3C-D, 4C-D, 5B, 6B, D, F, H, 7C-D, F, H, J, 8D-F, 9D-F, 10B, D, 12

Tranes xanthorrhoeae auct. - misidentification.

\section{Diagnosis}

The species is readily distinguishable from P. monopticus, as given in the diagnosis of the latter above.

\section{Etymology}

The specific epithet is dedicated to the late Dr Elwood Curtin Zimmerman, former weevil taxonomist at the ANIC who is renowned for his invaluable works on Australian weevils and who was the first to recognise the distinctiveness of this species among the type series of Tranes xanthorrhoeae.

\section{Material examined}

Holotype

AUSTRALIA • O'; "Kalbarri, W.A. / Sept. 1968 / G. Hill // C.G.L. Gooding / Collection / donated to / A.N.I.C. 1975 // HOLOTYPE / Paratranes zimmermani / Hsiao \& Oberprieler 2021”; ANIC.

Paratypes (all labelled "PARATYPE / Paratranes zimmermani / Hsiao \& Oberprieler 2021") AUSTRALIA • 2 exx.; "New / Holland”; NHMUK • 1 ex.; "Australia // Sharp Coll. / B.M. 1948336.”; NHMUK • 1 q, 1 ex.; “Australia / RMY'69 // E.Y. Western Coll. / B.M. 1924-176.”; NHMUK. - Western Australia • 1 ex.; "30890 // De / Boulay // Nov Holl / Occid. // Fry Coll. / 1905-100."; NHMUK • 1 ex.; "De / Boulay // Nov Holl / Occid. // Fry Coll. / 1905-100."; NHMUK • 1 ex.; "n.w.

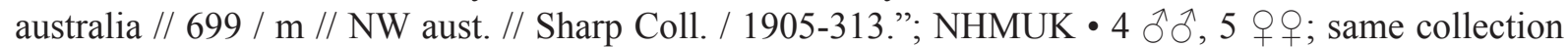

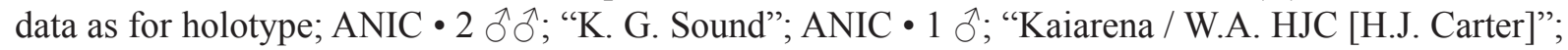
ANIC • 1 Oे, 1 o.; "Wembley Park / WA"; ANIC • 1 ex.; "Swan R. / W. Australia / J. Clark // G.A.K.

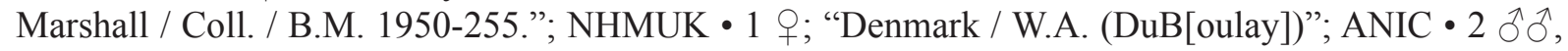
2 우; "Pinjarra, W.A. / E. Goerling"; ANIC • 1 ex.; "5192 / Melville Park, / W.A. / H. M. Giles. / 6.11.03 // G.A.K. Marshall / Coll. / B.M. 1950-255. // Tranes / sp. not in BM. / Det G.A.K. Marshall"; NHMUK • 1 o ; "F. H. Uther Baker / Stirling Ra. WA / 21.3.49 // F.H. UTHER BAKER / BEQUEST / 1992 // Tranes / monopticus Pasc. / J. Balfcur-Browne [sic] det. / Comp.type. // These three doubtfully Tranes / monopticus - check o. descr. / Not xanthorrhoeae - / det. F. H. Uther Baker / Femora edentate not T. roei // NOT / T. m."; ANIC • 1 O;; "F.H. Uther Baker / Jandakot / Western Australia / 17.IX.65 // F.H. UTHER BAKER / BEQUEST / 1992"; ANIC • 1 ô, 2 q o+; "3 mi. W. of Augusta, / WA. 34.19S 115.10E / 14.xi.69 Xanthorrhoea / inflorescences / E.B. Britton"; ANIC • 1 ex.; "WEST. AUST. / MADDINGTON / 10-XII-69 // ex collection / A. Walford-Huggins // Coll. / A. WRIGHT / 5133 // E. Gowing-Scopes / collection / BMNH(E) 2005-4 // Tranes / monopticus Pasc / E. Gowing-Scopes. det. / 1989"; NHMUK • 1 q; "Collie - WA, / 27 October 1985 / Xanthorrhoea sp. / R. Patterson I918”;

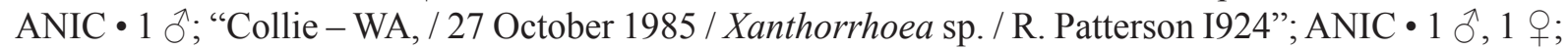
"AUSTRALIA, WA / Gnangara Pine / Plantation 30 km / NE of Perth, / 31.43S 116.17E / 09.x.1986 / G. Tribe // feeding on / flower stalk of / Xanthorrhoea / preissii // Tranes sp. (nov). / unnamed in BM (9) / R. Oberprieler 1988”; ANIC • 1 q: "[front] ROWLEY ROAD, / PEEL ESTATE, PERTH, / W.A. IN 32 11 'S 11555'E / 24 SEPT. 1995 / M. PETERSON // [back] ON GREEN CAUDEX / OF 
REGENERATING / XANTHORRHOEA / PREISSII IN BURNT / AREA OF SWAMP / 1440 - 15:40 HRS”; ANIC • 2 우; “ “34²4.257’S 119¹5.085’E / WA: Bremer Bay, W. of. / 23 Oct 2003, S. Neser / adults - flowers of Xanthorrhoea”; ANIC • 1 \%; “[front] 32॰12’09.4”S / 11552’29.7”E / 8 OCTOBER 2008 / M. PETERSON // [back] ON TOP OF FLOWERING / TIP OF GREEN NON- / FLOWERING

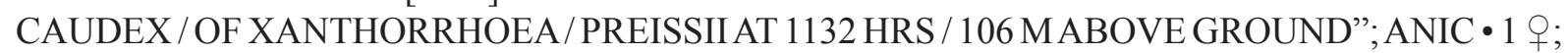
“[front] 32॰12'11.6”'S / 115'52'35.0”'E / 8 OCTOBER 2008 / M. PETERSON // [back] SPECIMEN 3.1m (1200 HR) / above GROUND NR / GROWING TIP OF / FLOWER SPIKE ON / XANTHORRHOEA PREISSII"; ANIC • 1 đ ; "xanthorrhoeae / Lea Swan R. // Co-type // PARALECTOTYPE / Tranes xanthorrhoeae Lea, 1898 / des. Hsiao \& Oberprieler 2020"; SAMA • 1 क; "Mt. Barker / W.A., Lea // $q$ // Co-type // Tranes I 10413 / xanthorrhoeae Lea / W. Australia. Cotype // NOT / xanthorrhoeae / Det. E.C. Zimmerman // PARALECTOTYPE / Tranes xanthorrhoeae Lea, 1898 / des. Hsiao \& Oberprieler 2020"; SAMA • 1 ex.; "UQIC Reg. / \#77514 // Tranes / xanthorrhoea [sic] / NWA Lea"; UQIC • 1 ex.; "WA: Yeal Nat Res / -31.3769 115.8094 / Banksia and heath / 9 Oct 2020 / J \& F Hort 12044"; ANIC• 1 ex.; "WA: Wandoo NP / -32.0662 116.5309/ Diverse heath / 10 Oct 2020 / J \& F Hort 11902"; ANIC • 1 ex.; same data except "J \& F Hort 11903"; ANIC • 1 ex.; same data except "J \& F Hort 12075"; ANIC - 1 ex.; same data except "J \& F Hort 12076"; ANIC • 1 ex.; same data except "J \& F Hort 12077"; ANIC. - New South Wales • 1 ex.; "Pascoe / Coll. / 93-60. // Lurnea / nsw"; NHMUK・ 2 ふぇ, 2 우우 "N.S.W."; ANIC • 1 \%; "Sydney"; ANIC • 1 क; "Hawkesbury R. / N. S. Wales // E. W. Ferguson / Collection"; ANIC • 1 ô, 1 क; "HEATHCOTE, N.S.W. // 27 $7^{\mathrm{TH}}$ OCTOBER, 1950 / I. BALDERSON // F.H. UTHER BAKER / BEQUEST / 1992"; ANIC • 1 đ’; “xanthorrhoeae / Lea Gosford // Elston has / from Q. // Tranes / xanthorrhoeae Lea / N. S. Wales // New genus / new species / Det. E.C. Zimmerman // PARALECTOTYPE / Tranes xanthorrhoeae Lea, 1898 / des. Hsiao \& Oberprieler 2020"; ANIC - 1 J, 1 q; "Sydney / Brown // Griffith Collection / Id. By A. M. Lea // Tranes / xanthorrhoeae / Lea N.S.W. 851 // Ditto / N. S. Wales // PARALECTOTYPE / Tranes xanthorrhoeae Lea, 1898 / des. Hsiao \& Oberprieler 2020"; SAMA.

\section{Type locality}

Kalbarri, Western Australia, Australia.

\section{Description}

SHAPE AND SIZE. Body elongate oval (Fig. 3C-D), length 7.3-10.1 mm in both sexes, width $0.46-0.48 \times$ length, very flat in lateral view (Fig. 4C-D).

COLOUR AND vestiture. Body and legs shiny black, semilustrous; body, femora and tibiae sparsely covered with very short pale setae, setae on tibiae slightly longer than on body and femora; funicles, clubs and tarsi densely covered with pale to yellowish setae, longer than short pale setae on body, femora and tibiae.

Rostrum. Moderately long, ca $1.3-1.4 \times$ as long as pronotum in both sexes, robust, slightly curved ventrad, dorsoventrally flattened, slightly broadened apically in dorsal view, coarsely punctate dorsally, punctures very fine in distal half, proximal half with paired dorsomedian and dorsolateral carinae, the latter lower than the former.

EyES. Subcircular in outline, slightly convex but not protruding (Fig. 4C-D).

ANTENNAE. Inserted at about distal third of rostrum in both sexes (Fig. 4C-D); scapes not reaching eye; funicles with segment 1 ca $0.8-1.1 \times, 1.5-2.4 \times, 1.5-2.1 \times, 1.5-2.1 \times, 1.4-1.7 \times$ and $1.3-1.7 \times$ as long as segments 2 to 7 , respectively; clubs stout, fused with segment 7 of funicle, ca $1.6 \times$ as long as wide, densely and finely pubescent (Fig. 5B). 

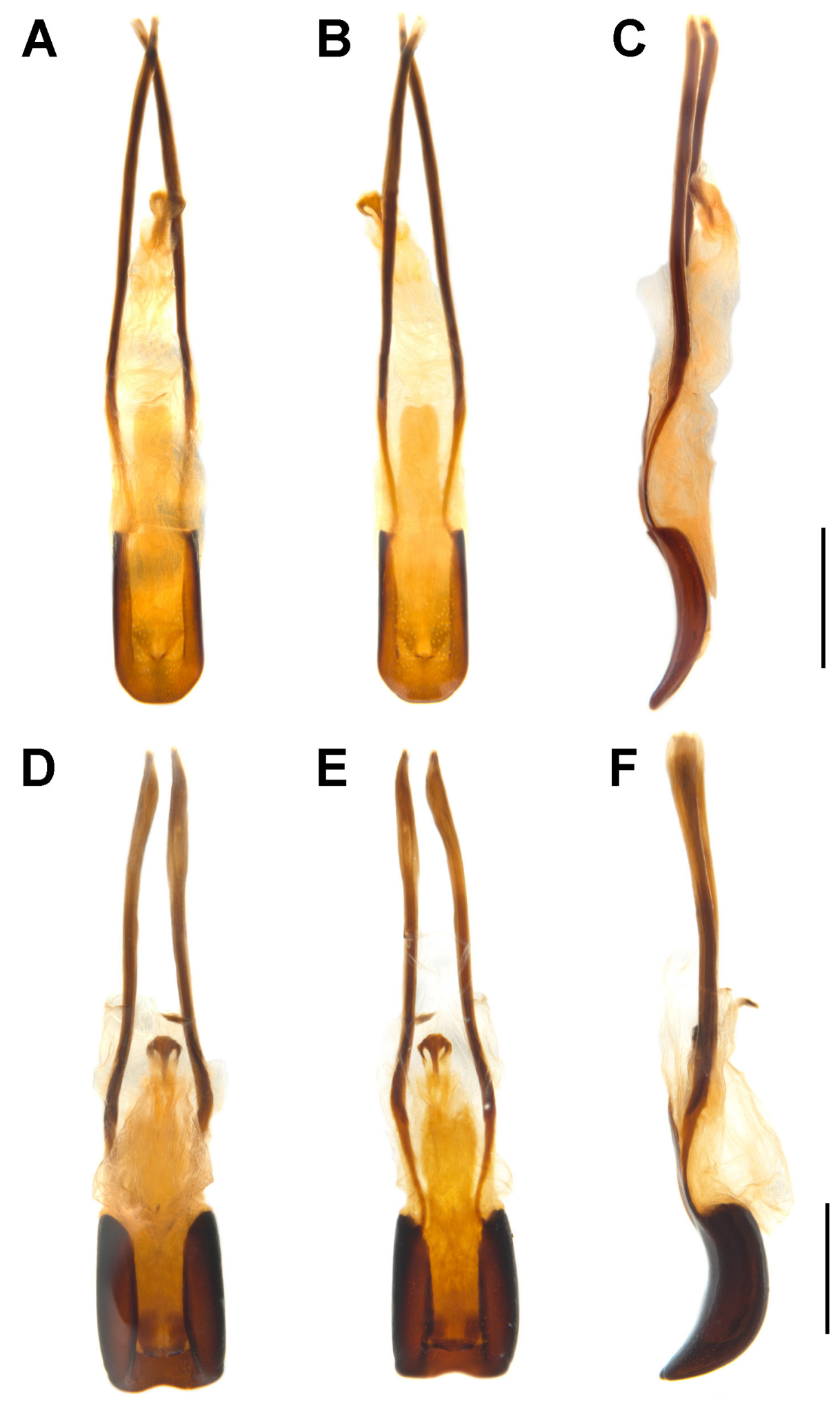

Fig. 8. Penis of Paratranes Zimmerman, 1994. A. P. monopticus (Pascoe, 1870), dorsal view (Griffith Uni., Qld). B. P. monopticus, ventral view (Griffith Uni., Qld). C. P. monopticus, lateral view (Griffith Uni., Qld). D. P. zimmermani sp. nov., dorsal view (Kalbarri, WA). E. P. zimmermani sp. nov., ventral view (Kalbarri, WA). F. P. zimmermani sp. nov., lateral view (Kalbarri, WA). Scale bars $=1.0 \mathrm{~mm}$. 
Pronotum. Roundly trapezoidal, apex ca $0.6 \times$ as wide as base; anterior margin slightly emarginate medially, posterior margin protruding medially, forming obtuse median lobe, sides distinctly arcuate; disc nearly flat; surface densely and coarsely punctate, with elongate longitudinal impunctate region medially, punctures separate but confluent and vague laterally; prosternum with slightly depressed, subrounded region sparsely punctate medially (Fig. 6B).

SCUTELLAR SHIELD. Roundly pentagonal to subcircular.

ELYTRA. Ca $2.7-3.0 \times$ as long as pronotum, jointly ca $0.6-0.7 \times$ as broad as long, distinctly broader than base of pronotum; humeri broadly rounded, slightly protruding; surface nearly flat, shallowly and coarsely punctate in rows, forming shallowly depressed striae.

Legs. Femora distinctly sulcate beneath, without ventral tooth (Fig. 6D); tibiae with arcuate premucro smaller than uncus (Fig. 6F); tarsi with claws free, divergent (Fig. 6H).

Terminalia. Tergite VIII of female subtrapezoidal (Fig. 7C), ca $0.9-1.1 \times$ as long as wide; sternite VIII of male broadly crescentic, sclerotised, apical margin rounded to truncate, basal margin strongly sclerotised (Fig. 7F); spiculum gastrale widely concave apically, base weakly sclerotised (Fig. 7H). Tegmen with
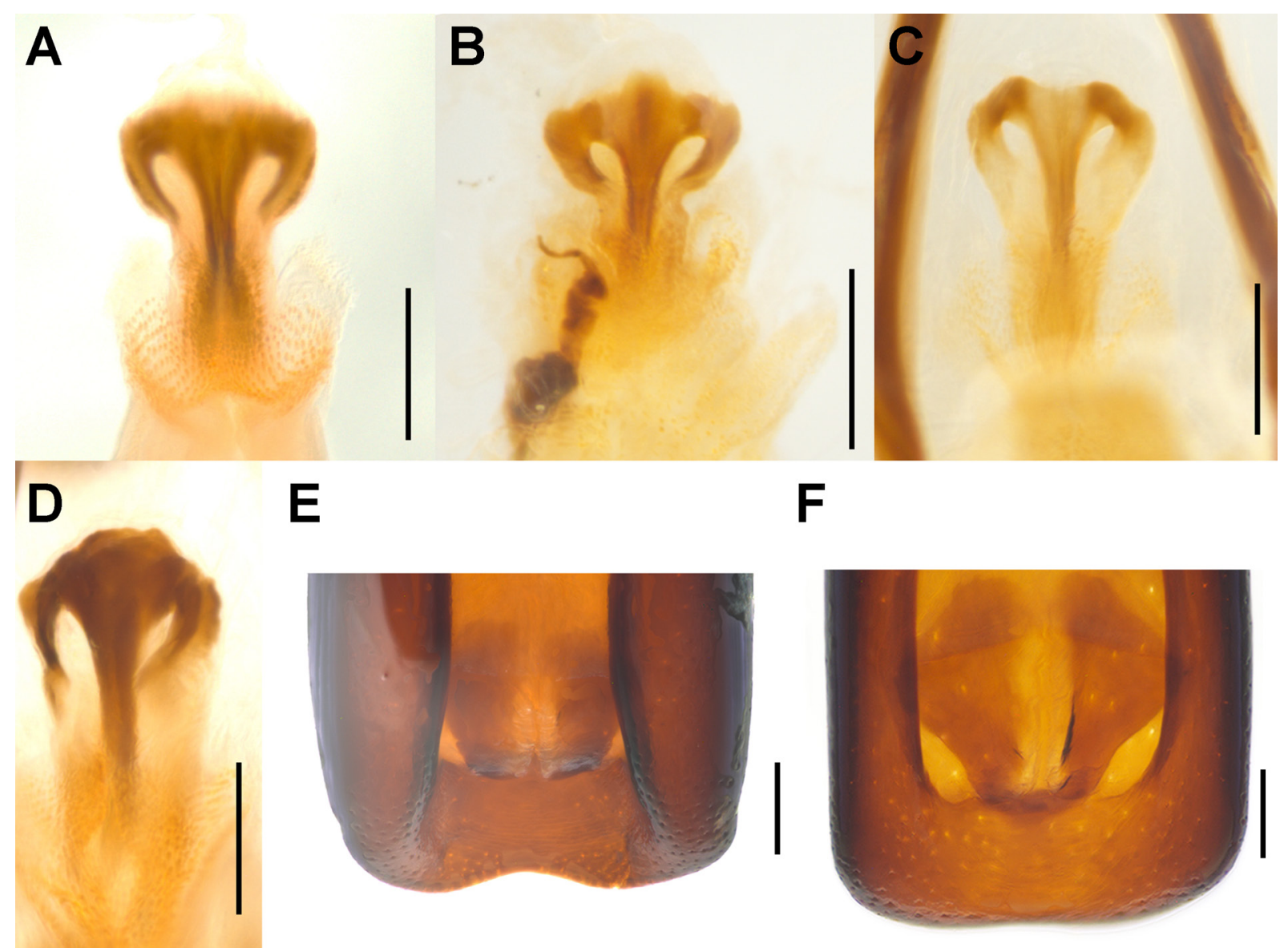

Fig. 9. Endophallus and apex of penis of Paratranes Zimmerman, 1994. A. P. monopticus (Pascoe, 1870), apical sclerite (Griffith Uni., Qld). B. P. monopticus, ditto (Lucindale, SA). C. P. monopticus, ditto (Deepdene, WA). D. P. zimmermani sp. nov., ditto (Kalbarri, WA). E. P. zimmermani sp. nov., apex of penis (Kalbarri, WA). F. P. zimmermani sp. nov., ditto (NSW). Scale bars $=0.2 \mathrm{~mm}$. 
complete, subcircular ring, manubrium slender, distinctly shorter than parameroid lobes (Fig. 7J); penis thick (ca $1.4-1.6 \times$ as long as wide), sides straight, parallel or merely slightly narrowing apicad, dorsum flat, laterally distinctly sclerotised, medially broadly grooved, apical margin subtruncate, medially slightly emarginate (Fig. 8D-F); endophallus with apical sclerite slightly protuberant (Fig. 9D). Gonocoxites thick, short, apically bluntly rounded (Fig. 10B), ca 1.5-2.0 $\times$ as long as wide, proximal gonocoxite ca
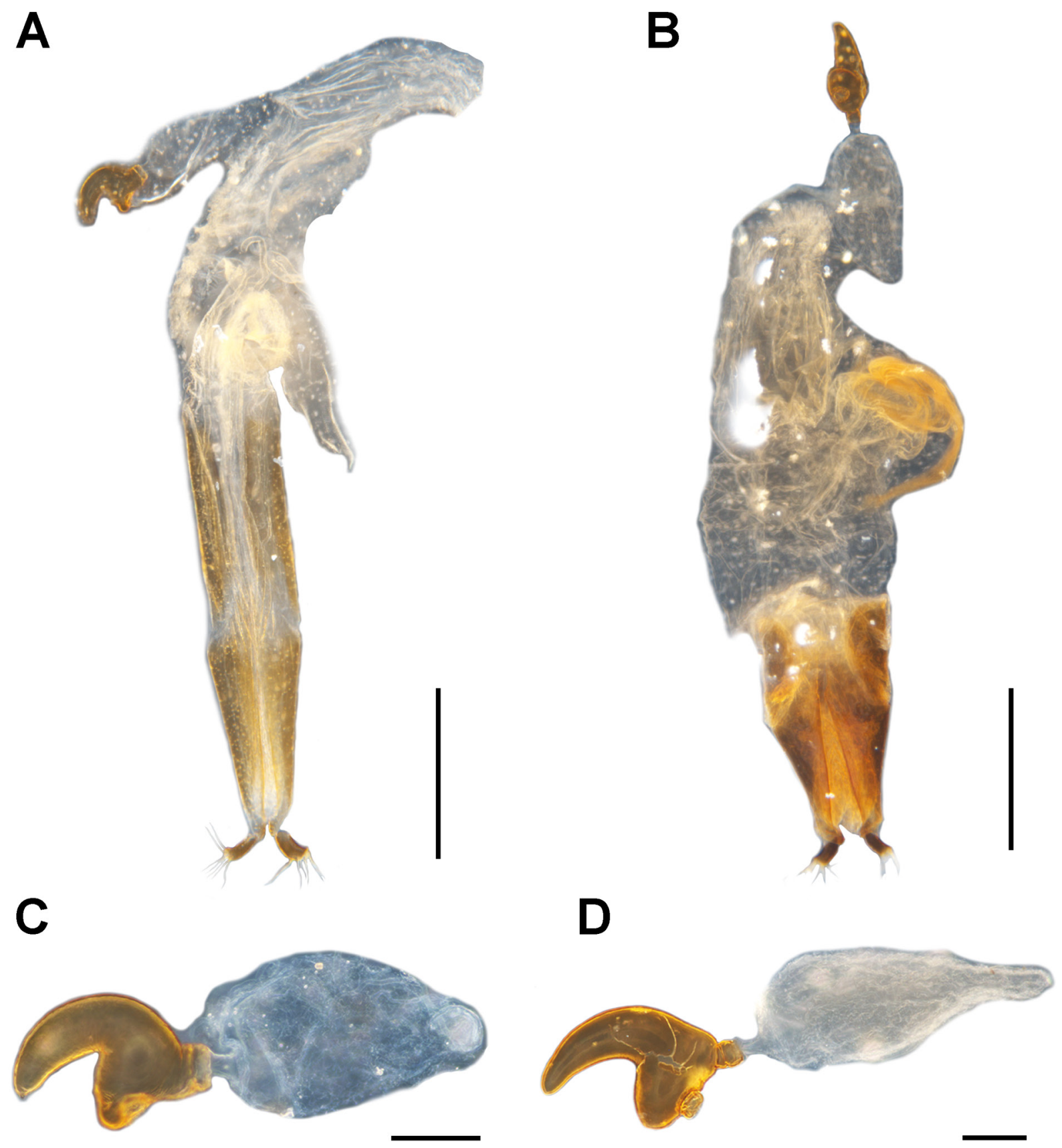

Fig. 10. Female genital structures of Paratranes Zimmerman, 1994. A. P. monopticus (Pascoe, 1870), ovipositor (Homebush, NSW). B. P. zimmermani sp. nov., ditto (Wembley, WA). C. P. monopticus, spermatheca with gland (Homebush, NSW). D. P. zimmermani sp. nov., ditto (Wembley, WA). Scale bars: $\mathrm{A}-\mathrm{B}=0.5 \mathrm{~mm} ; \mathrm{C}-\mathrm{D}=0.2 \mathrm{~mm}$. 


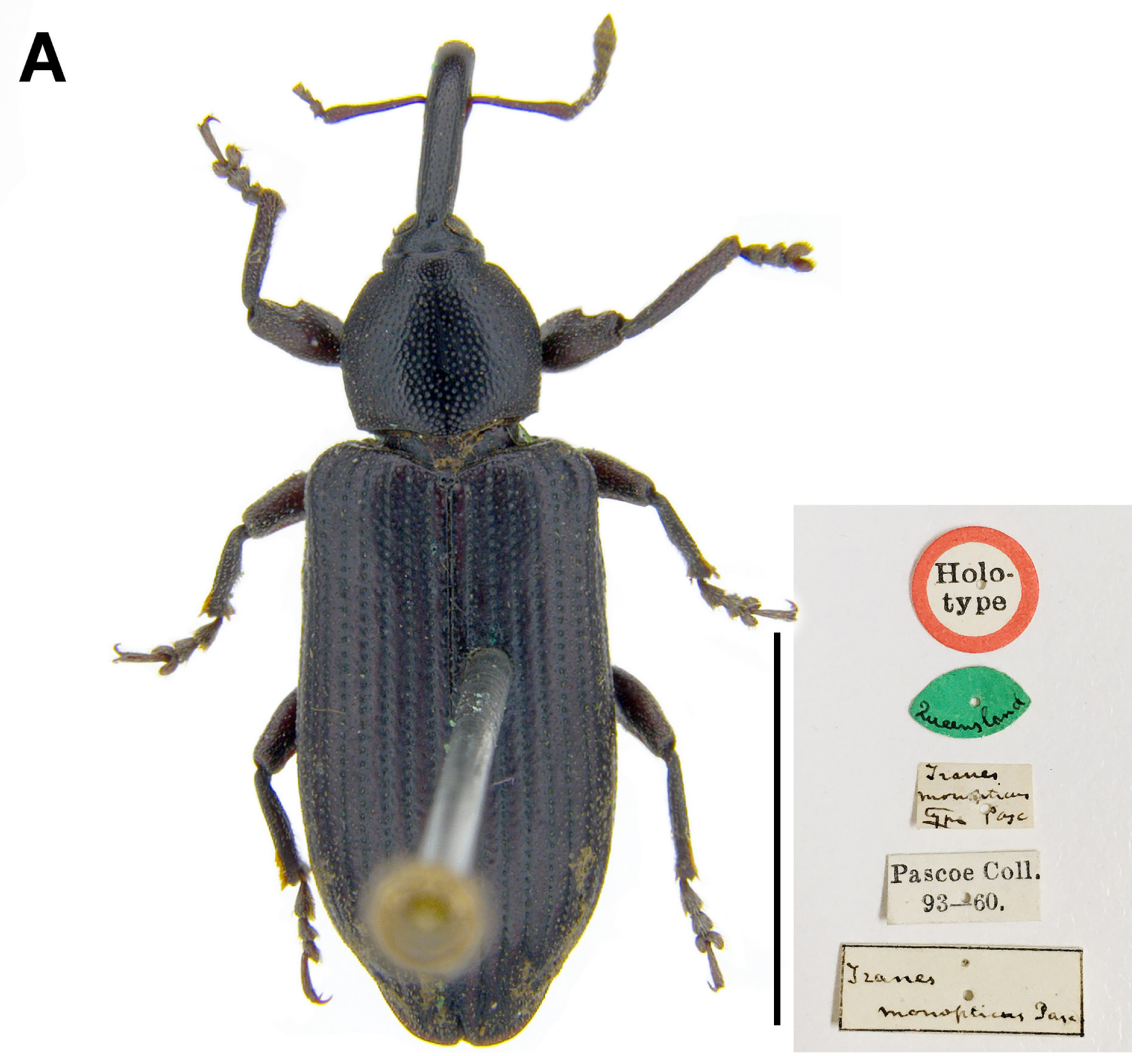

B

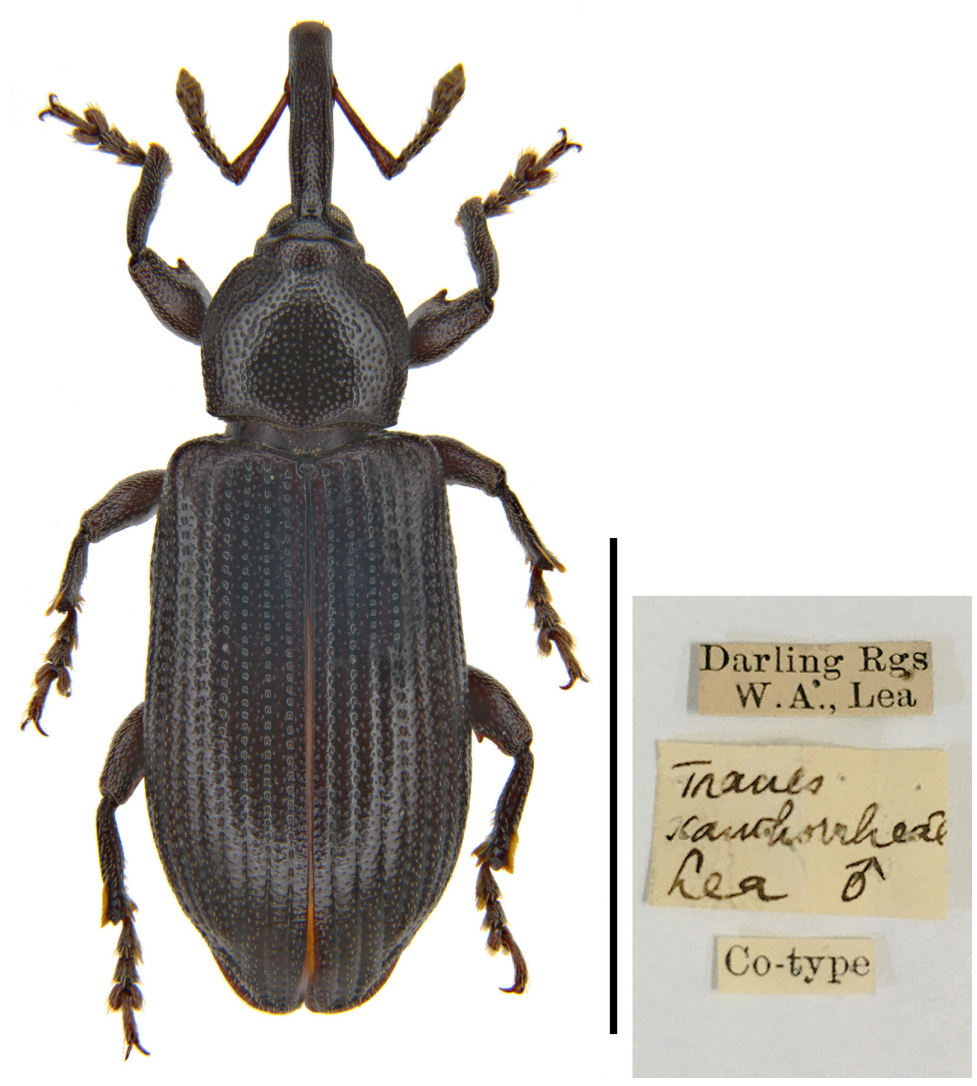

Fig. 11. A. Tranes monopticus Pascoe, 1870, holotype (NHMUK). B. Tranes xanthorrhoeae Lea, 1898, lectotype (here designated) (SAMA). Scale bars $=5.0 \mathrm{~mm}$. 
$0.8-1.1 \times$ as long as distal gonocoxite; gonostyli cylindrical, setose apically; bursa copulatrix without bands of spicules; spermatheca thick, right-angled, gland thick, swollen, narrowing apicad (Fig. 10D).

\section{Distribution}

Based on the records we have seen, this species has two disjunct populations, one in coastal regions around central New South Wales (Sydney) and another in southwestern Western Australia (Fig. 12). Most of our examined specimens were collected in Western Australia, indicating that the species is mainly distributed there.

\section{Natural history}

Like P. monopticus, this species appears to be associated with grasstrees, having been taken from the flower stalks and green caudex of regenerating plants in a burnt area of swamp during the daytime. Adults have also been observed feeding on flower stalks of grasstrees (Fig. 13). They are cautious and quickly dropped to the ground when disturbed (J. and F. Hort, pers. obs.). The only host recorded for this species (on labels) is Xanthorrhoea preissii in Western Australia, but specimens from New South Wales imply that the species is associated with other Xanthorrhoea species in the east, such as X. australis and X.johnsonii.

\section{Remarks}

The assessment of the taxonomic status of this species varied between being considered conspecific with (females of) P. monopticus by Lea (1898) (as Tranes xanthorrhoeae) and as representing a different genus

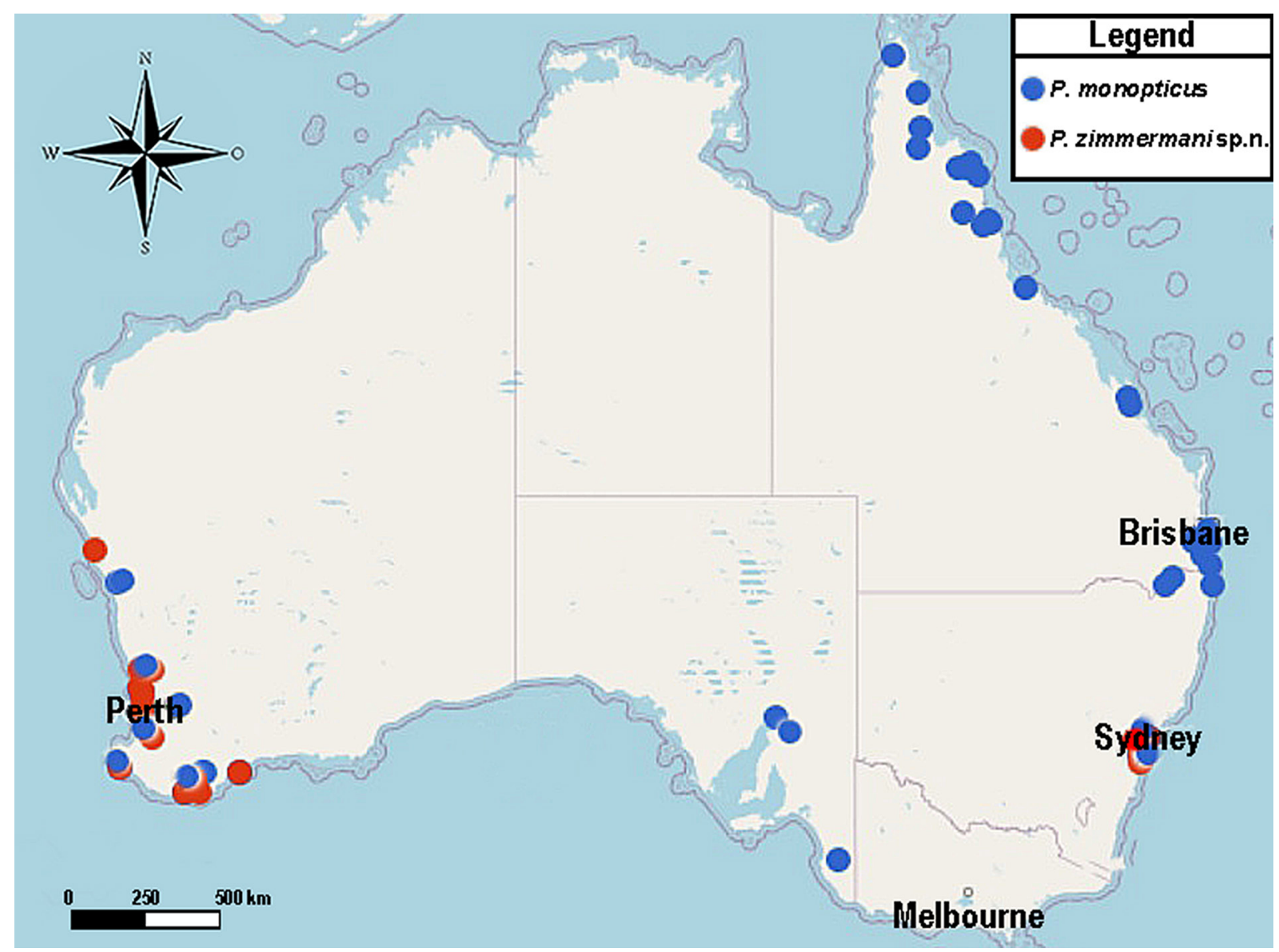

Fig. 12. Geographical distribution of Paratranes Zimmerman, 1994 in Australia. 
"allied to Paratranes" by Zimmerman (1994). While its status as a species distinct from P. monopticus is clear from several morphological differences (in particular in the male genitalia), we do not regard these differences as significant enough to treat it as a genus distinct from Paratranes, especially in comparison with the differences between the other genera of the Tranes group. Zimmerman (1994) did not seem convinced of a separate generic status for it either, because he did not name such a genus in his key to the genera of the Tranes group, as he did with Paratranes and other new genera.

Specimens of $P$. zimmermani sp. nov. in New South Wales differ slightly from those at the type locality in Western Australia (Kalbarri) in their male genitalia, by having a wider and shallower apical opening of the median dorsal groove of the penis (Fig. 9E-F), but such a wide and shallow opening also occurs in specimens of populations further south in Western Australia (e.g., Collie), and in the absence of other morphological differences we regard this difference as intraspecific variation rather than signifying different species. However, the apparent widely disjunct distribution of $P$. zimmermani sp. nov. between south-eastern and south-western Australia is remarkable in view of the much wider and likely continuous range of P. monopticus (see Fig. 12).

\section{Discussion}

\section{Redefinition of Paratranes Zimmerman, 1994}

Zimmerman (1994) excluded Tranes monopticus from Tranes and established a new genus, Paratranes, for it, differentiating it from all other genera of the Tranes group by its slender and depressed body, the forehead slightly narrower than the basal width of the rostrum, the antennae inserted at about the distal third of the rostrum, funicular segment 2 being distinctly shorter than 1 and segment 7 incorporated

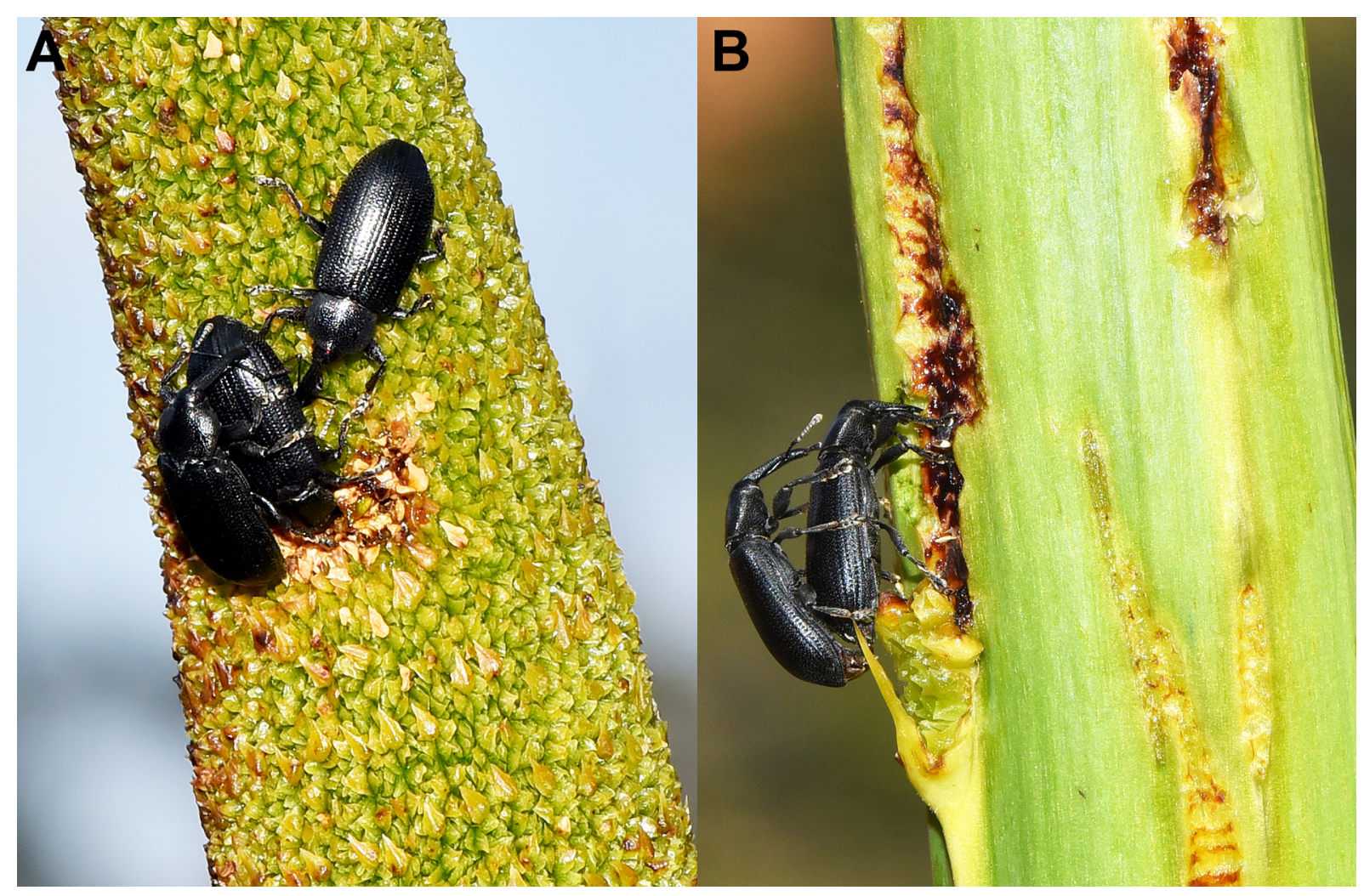

Fig. 13. Paratranes zimmermani sp. nov. in their natural habitats. A. Adults feeding on flower stalks of grasstrees. B. Copulation. ( ${ }^{\odot}$ Jean and Fred Hort). 
into the club, confluent procoxal cavities and nearly contiguous procoxae, distinctly sulcate and dentate femora, distinct protibial uncus, distal combs of meso- and metatibiae continuing around the tibial apices and extending to the middle or slightly before the middle of the tibiae and by the rounded dorso-apical corner of the metatibiae. Zimmerman's concept of Paratranes did, however, not include P. zimmermani sp. nov., which he deemed to represent a different genus based on its longer funicular segment 2 (subequal to 1), edentate femora and very small protibial uncus. Given that such small differences also occur in other weevil genera (e.g., a femoral tooth of varying size in Siraton), together with the great overall morphological and ecological similarities of $P$. monopticus and $P$. zimmermani sp. nov., we regard both these species as representing the same genus and hence here revise the concept of Paratranes to include both these species and a more comprehensive suite of their morphological characters, including those of the terminalia (see redescription of the genus above).

\section{Distribution and intraspecific variation of Paratranes}

The distribution of Paratranes is considerably wide and broadly congruent with that of Xanthorrhoea, except that it appears much more fragmented, with disjunct populations in Western Australia, South Australia and eastern Australia and none in central Australia (as known) and seemingly also none in Victoria and Tasmania. Despite the disjunct distributions of both species in western and eastern Australia, the morphological differences are very minor among their different populations (see details in the Remarks section of the species), and, in view of the distinct interspecific differences in other genera in the Tranes group (e.g., Tranes and Miltotranes), we recognise only two species in Paratranes. The very small morphological divergence between the eastern and western Australian populations of both species indicates that both were more widely and continuously distributed in Australia in the past and have developed their disjunct distribution relatively recently. Future studies using a molecular approach are needed to explore the evolutionary history of the genus and its species.

\section{Morphological divergence between Paratranes monopticus and $\boldsymbol{P}$. zimmermani sp. nov.}

The morphological differences between $P$. monopticus and $P$. zimmermani sp. nov. are quite conspicuous, both in external and in genital characters, and, interestingly, they include the female terminalia, which are usually similar in the same genus in weevils. Especially noteworthy is the difference in the ovipositor, which is much more pronounced than in the other genera of the Tranes group, e.g., Demyrsus and Siraton (Hsiao \& Oberprieler 2020), and suggests different modes of oviposition and hence of sites of larval development between the species, such that $P$. monopticus may lay its eggs into deeper-lying tissues and that its larvae develop in different plant parts than those of $P$. zimmermani sp. nov.. This may enable the two species to co-exist in sympatry and even on the same hostplants (i.e., character displacement; Brown \& Wilson 1956), as appears to be the case in locations where both have been collected (Perth, Pinjarra, Mt Barker, Bremer Bay and Stirling Range in WA and Gosford and Sydney in NSW). Although their distribution ranges overlap in Western Australia and central New South Wales, it appears that P. zimmermani sp. nov. is more common in the former and P. monopticus in the latter region.

\section{Acknowledgments}

We are indebted to Max Barclay (NHMUK), Susan Wright (QMBA) and Justin S. Bartlett (QDPI) for their assistance in borrowing specimens for this study, and Jean and Fred Hort for photographs of Paratranes zimmermani sp. nov. We cordially thank the editor and anonymous reviewers for their suggestions to improve the manuscript.

\section{References}

Alonso-Zarazaga M.A. \& Lyal C.H.C. 1999. A World Catalogue of Families and Genera of Curculionoidea (Insecta: Coleoptera) (excepting Scolytidae and Platypodidae). Entomopraxis, S.C.P., Barcelona, Spain. 
Anderson R.S., Oberprieler R.G. \& Setliff G.P. 2018. A review of the Araucaria-associated weevils of the tribe Orthorhinini (Coleoptera: Curculionidae: Molytinae), with description of new species of Ilacuris Pascoe, 1865 and Notopissodes Zimmerman \& Oberprieler, 2014 and a new genus, Kuschelorhinus Anderson \& Setliff. Diversity 10 (3): 54. https://doi.org/10.3390/d10030054

Brown W.L. \& Wilson E.O. 1956. Character displacement. Systematic Zoology 5: 49-64.

Bush Heritage Australia. 2020. Grass trees. Available from https://www.bushheritage.org.au/species/grass-trees [accessed 27 Aug. 2020].

Froggatt W.W. 1896. The entomology of the grass-trees (Xanthorrhoea). Proceedings of the Linnean Society of New South Wales 21: 74-87.

Froggatt W.W. 1907. Australian Insects. William Brooks \& Co., Sydney.

Hawkeswood T.J. 1985. Notes on some beetles (Coleoptera) associated with Xanthorrhoea johnsonii (Xanthorrhoeaceae) in the Brisbane area, south-east Queensland. Victorian Naturalist 102: 162-166.

Hsiao Y. \& Oberprieler R.G. 2020. A review of the trunk-boring cycad weevils in Australia, with description of a second species of Demyrsus Pascoe, 1872 (Coleoptera: Curculionidae: Molytinae). Austral Entomology 59 (4): 677-700. https://doi.org/10.1111/aen.12498

Lamont B.B., Wittkuhn R. \& Korczynskyj D. 2004. Turner Review No. 8. Ecology and ecophysiology of grasstrees. Australian Journal of Botany 52: 561-582. https://doi.org/10.1071/BT03127

Lea A.M. 1898. Descriptions of new species of Australian Coleoptera. Part V. Proceedings of the Linnean Society of New South Wales 23: 521-645. Available from https://www.biodiversitylibrary.org/page/2909639 [accessed 13 Aug. 2021].

Lea A.M. 1929. Descriptions of new species of Australian Coleoptera. XX. Proceedings of the Linnean Society of New South Wales 54: 519-549. Available from https://www.biodiversitylibrary.org/page/35068712 [accessed 13 Aug. 2021].

Legalov A.A. 2018. Annotated key to weevils of the world. Part 2. Subfamily Molytinae (Coleoptera, Curculionidae). Ukrainian Journal of Ecology 8: 340-350.

Lyal C.H.C. 2014. 3.7.7 Molytinae Schoenherr, 1823. In: Leschen R.A.B. \& Beutel R.G. (eds) Handbook of Zoology. Arthropoda: Insecta: Coleoptera, Beetles. Volume 3: Morphology and Systematics (Phytophaga): 529-570. Walter de Gruyter, Berlin.

Mulder R.H. 1964. Insects associated with 'Xanthorrhoea sp.' Journal of the Entomological Society of Australia (N.S.W.) 1: 12.

Oberprieler R.G. 1995. The weevils (Coleoptera: Curculionoidea) associated with cycads. 1. Classification, relationships, and biology. In: Vorster P. (ed.) Proceedings of the Third International Conference on Cycad Biology: 295-334. The Cycad Society of South Africa, Pretoria.

Oberprieler R.G. 2004. "Evil weevils" - the key to cycad survival and diversification? In: Lindstrom A.J. (ed.) The Biology, Structure and Systematics of the Cycadales, Proceedings of the Sixth International Conference on Cycad Biology: 170-194. Nong Nooch Tropical Botanical Garden, Thailand.

Oberprieler R.G. \& Caldara R. 2012. Siraton devillei Hustache (Coleoptera: Curculionidae), the mysterious weevil from the Isle of Elba: exiled no longer. Zootaxa 3573 (1): 55-58.

https://doi.org/10.11646/zootaxa.3573.1.6

Oberprieler R.G., Anderson R.S. \& Marvaldi A.E. 2014. Curculionoidea Latreille, 1802: introduction, phylogeny. In: Leschen R.A.B. \& Beutel R.G. (eds) Handbook of Zoology. Arthropoda: Insecta: Coleoptera, Beetles. Volume 3: Morphology and Systematics (Phytophaga): 285-301. Walter de Gruyter, Berlin. 
Pascoe F.P. 1870. Descriptions of some genera and species of Australian Curculionidae. Transactions of the Entomological Society of London 1870 (2): 181-209, 445-484.

Pullen K.R., Jennings D. \& Oberprieler R.G. 2014. Annotated catalogue of Australian weevils (Coleoptera: Curculionoidea). Zootaxa 3896 (1): 1-481. https://doi.org/10.11646/zootaxa.3896.1.1

Schenkling S. \& Marshall G.A.K. 1936. Curculionidae: Prionomerinae, Aterpinae, Amalactinae, Haplonychinae, Omophorinae. In: Junk W. \& Schenkling S. (eds) Coleopterorum Catalogus. Pars 150. W. Junk, s'Gravenhage.

Shin S., Clarke D.J., Lemmon A.R., Moriarty-Lemmon E., Aitken A.L., Haddad S., Farrell B.D., Marvaldi A.E., Oberprieler R.G. \& McKenna D.D. 2017. Phylogenomic data yield new and robust insights into the phylogeny and evolution of weevils. Molecular Biology and Evolution 35: 823-836. https://doi.org/10.1093/molbev/msx324

Zimmerman E.C. 1994. Australian Weevils (Coleoptera: Curculionoidea). Volume I. Orthoceri. Anthribidae to Attelabidae. The Primitive Weevils. CSIRO, Melbourne.

Manuscript received: 11 November 2020

Manuscript accepted: 4 August 2021

Published on: 16 September 2021

Topic editor: Nesrine Akkari

Section editor: Max Barclay

Desk editor: Pepe Fernández

Printed versions of all papers are also deposited in the libraries of the institutes that are members of the EJT consortium: Muséum national d'histoire naturelle, Paris, France; Meise Botanic Garden, Belgium; Royal Museum for Central Africa, Tervuren, Belgium; Royal Belgian Institute of Natural Sciences, Brussels, Belgium; Natural History Museum of Denmark, Copenhagen, Denmark; Naturalis Biodiversity Center, Leiden, the Netherlands; Museo Nacional de Ciencias Naturales-CSIC, Madrid, Spain; Real Jardín Botánico de Madrid CSIC, Spain; Zoological Research Museum Alexander Koenig, Bonn, Germany; National Museum, Prague, Czech Republic. 